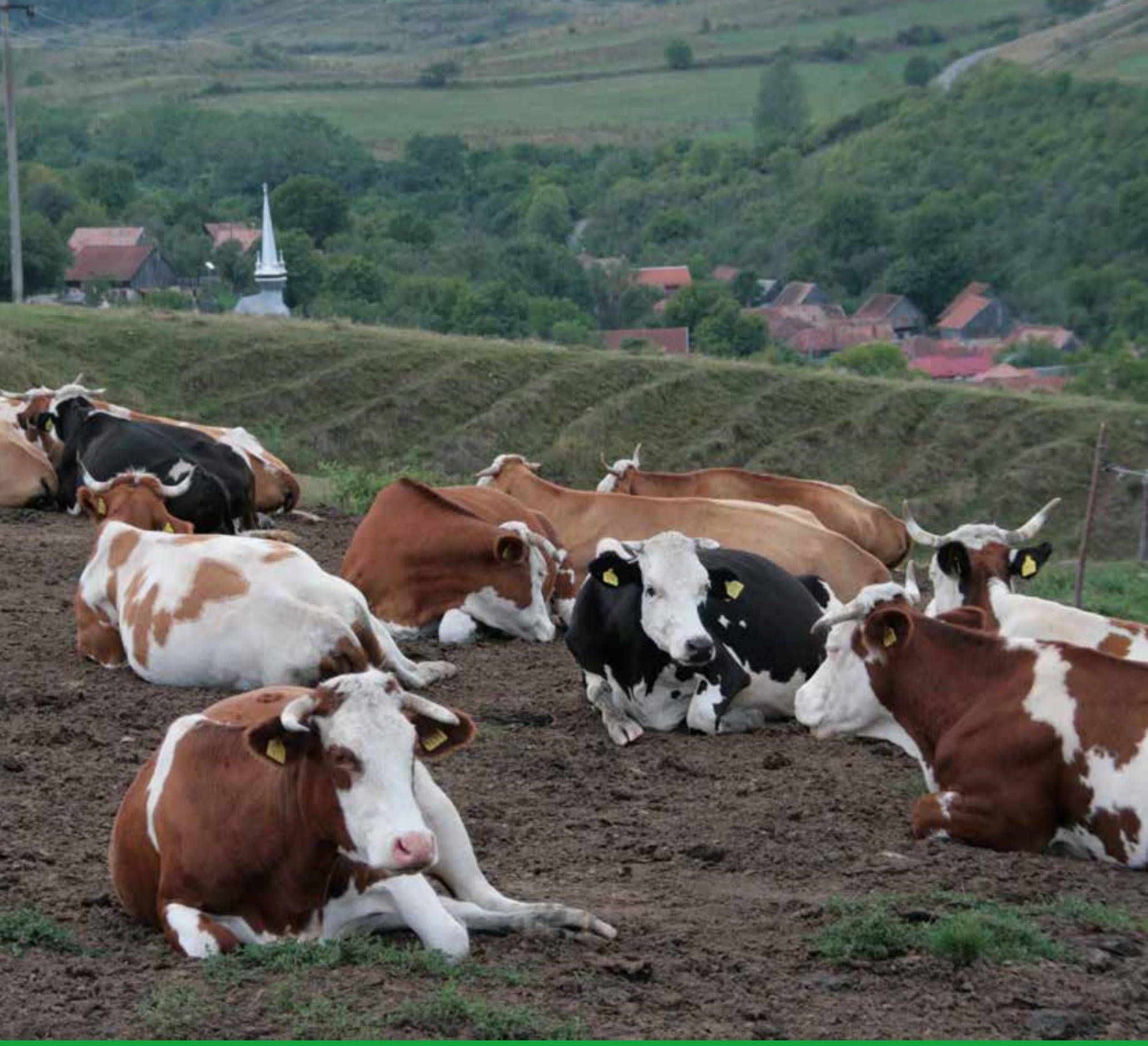

\title{
Opportunities for improving the dairy sector in Romania
}

Wim Zaalmink, Ron Bergevoet, Co Daatselaar and Bert Smit 



\section{Opportunities for improving the dairy sector in Romania}

Wim Zaalmink, Ron Bergevoet, Co Daatselaar and Bert Smit

This study was carried out by Wageningen Economic Research and was commissioned and financed by the Dutch Ministry of Agriculture, Nature and Food Quality and funding partners within the context of the 'International Cooperation research theme of the Policy Support Research Tasks (project number BO-27.04-001-012) within the Dutch Private Partnership Dairy Development Romania

Wageningen Economic Research

Wageningen, March 2020

REPORT

2020-015

ISBN 978-94-6395-316-0 
Wim Zaalmink, Ron Bergevoet, Co Daatselaar en Bert Smit, 2020. Opportunities for improving the dairy sector in Romania. Wageningen, Wageningen Economic Research, Report 2020-015. 54 pp.; 10 fig.; 1 tab.; 13 ref.

Roemenië is een melkimporterend land. De melkveehouderij in het land is kleinschalig maar biedt perspectief. Het kennisniveau bij veehouders is nog laag. Het agrarisch onderwijs is onvoldoende ontwikkeld voor goed gekwalificeerde arbeid. Nederlandse bedrijven zijn actief in Roemenië om de melkveehouderij te ontwikkelen maar lopen tegen dit lage kennisniveau aan. Dit rapport beschrijft de ervaringen van kennisoverdracht naar veehouders en adviseurs in het centraal gelegen Transsylvanië.

Romania is a milk importing country. Dairy farming in the country is small-scale but offers good prospects. The level of agricultural knowledge among farmers is still low due to insufficient agricultural education. Dutch businesses are active in Romania to develop dairy farming but are running up against this low level of knowledge. This report describes the experiences of transferring knowledge to farmers and advisors in central Transylvania.

Key words: Romania, Transylvania, dairy farming, knowledge transfer

This report can be downloaded for free at https://doi.org/10.18174/514883 or at www.wur.eu/economic-research (under Wageningen Economic Research publications).

(C) 2020 Wageningen Economic Research

P.O. Box 29703, 2502 LS The Hague, The Netherlands, T +31 (0)70 3358330 ,

E communications.ssg@wur.nl, http://www.wur.eu/economic-research. Wageningen Economic Research is part of Wageningen University \& Research.

\section{(cc) BY-NC}

This work is licensed under a Creative Commons Attribution-Non Commercial 4.0 International License.

(C) Wageningen Economic Research, part of Stichting Wageningen Research, 2020

The user may reproduce, distribute and share this work and make derivative works from it. Material by third parties which is used in the work and which are subject to intellectual property rights may not be used without prior permission from the relevant third party. The user must attribute the work by stating the name indicated by the author or licensor but may not do this in such a way as to create the impression that the author/licensor endorses the use of the work or the work of the user. The user may not use the work for commercial purposes.

Wageningen Economic Research accepts no liability for any damage resulting from the use of the results of this study or the application of the advice contained in it.

Wageningen Economic Research is ISO 9001:2015 certified.

Wageningen Economic Research Report 2020-015 | Project code 2282300110

Cover photo: Wim Zaalmink/Wageningen University \& Research 


\section{Contents}

$\begin{array}{ll}\text { Preface } & 5\end{array}$

$\begin{array}{ll}\text { Summary } & 6\end{array}$

S.1 Prospects for the development of the Romanian dairy sector 6

$\begin{array}{lll}\text { S.2 Education and training of farmers is key to success } & 6\end{array}$

S.3 Knowledge transfer through practice-based training programmes $\quad 7$

$\begin{array}{ll}\text { Samenvatting } & 8\end{array}$

S.1 Veel kansen voor zuivelproductie in Roemenië Romania $\quad 8$

S.2 Onderwijs en training van veehouders is belangrijke succesfactor $\quad 8$

S.3 Kennisoverdracht via praktijkgerichte trainingsprogramma's 9

1

$\begin{array}{ll}\text { Dairy industry in Romania } & 10\end{array}$

1.1 Background 10

1.2 Objective of the study 11

$\begin{array}{lll}1.3 & \text { Structure of this report } & 11\end{array}$

$2 \quad$ Milk production and milk market in Romania

2.1 Trade $\quad 12$

2.2 Primary production $\quad 14$

$\begin{array}{lll}2.3 & \text { Foreseen developments } & 16\end{array}$

$\begin{array}{lll}2.4 & \text { SWOT analysis of Dairy farming in Romania } & 18\end{array}$

$\begin{array}{lll}2.5 & \text { Conclusion and possible implications } & 18\end{array}$

$3 \quad$ Implementing a training programme $\quad 20$

$\begin{array}{lll}3.1 & \text { The role of study groups } & 20\end{array}$

$\begin{array}{lll}3.2 & \text { Development of entrepreneurship } & 21\end{array}$

4

$\begin{array}{ll}\text { The project } & 22\end{array}$

$\begin{array}{lll}4.1 & \text { Participants } & 22\end{array}$

4.2 Project description $\quad 23$

$\begin{array}{lll}4.3 & \text { Learnings of the participants } & 25\end{array}$

$\begin{array}{llr}5 & \text { Project learnings } & \mathbf{2 7}\end{array}$

$\begin{array}{lll}5.1 & \text { Observations on the dairy project } & 27\end{array}$

5.2 Recommendations $\quad 28$

$\begin{array}{ll}\text { References and websites } & \mathbf{2 9}\end{array}$

$\begin{array}{ll}\text { Appendix } 1 & 30\end{array}$

Appendix 2 Introduction to the background, principles and application of interactive strategic management 



\section{Preface}

Romania is a country with a good potential for food production with high quality. But milk and dairy production has been declining in recent years despite the fact that the demand for these products increases. The circumstances for milk production are good but lack of knowledge about modern agricultural production systems seems to be a problem.

Private companies active in dairy farming in Romania asked Wageningen Research to support them in the development of the dairy chain by organising knowledge transfer to farmers and advisors, especially in the central region of Transylvania, with a focus on family-sized farms. This resulted in the project 'Dairy Chain Development Romania', which was partly financed by the private companies and the Topsector Agri Food.

A training programme focused on vocational and entrepreneurial knowledge was set up. The results and lessons learned are described in this report. The coordination in Romania was carried out by Martin de Jong and Irina Gheorge (The Friesian SRL). Many other representatives of Dutch and Romanian companies, farmers' organisations, government and universities were involved. We thank them for their specific contributions to the project.

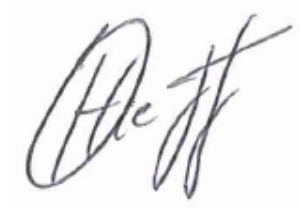

Ir. O. Hietbrink, Olaf

Business Unit Manager Wageningen Economic Research

Wageningen University \& Research 


\section{Summary}

\section{S.1 Prospects for the development of the Romanian dairy sector}

In Transylvania there are good prospects for family farms to develop to between 100 and 200 dairy cows and between 200 and 500 ha of land. The farms have several strategies for further development: specialisation, cooperation with other farms, diversifying (e.g. own processing of milk, tourism) and moving to organic production. Given the history, current cooperatives are not seen as the primary representatives of farmers' interests. But new and regional cooperatives with young agricultural members might be able to take on that role.

The need for knowledge and the sense of urgency for acquisition of new knowledge varies between farmers. Most of the younger generation have visited farms abroad, which changed their view on possibilities and about other ways of farming. International experience of the farmer is very important for the success of the farm. Traditionally, farmers often are not aware of spending time on learning activities as working time.

Study groups as a way of knowledge development and knowledge sharing are therefore difficult to start up in Romania. The younger generation of farmers has a different opinion on this and will be more willing to participate.

The trade deficit in milk and milk products is increasing substantially and the self-sufficiency rate for dairy products is decreasing. The main reason is the reduction in domestic production due to a decrease in the number of dairy cows.

The cost price of milk is lower compared to the Netherlands and comparable to the cost price in Poland. Low costs of land and labour are the main components of this lower cost price.

For the average farm, the farmer's milk price is lower than the European average. This is caused by the higher collection costs and lower protein and fat contents. However, in general there are favourable circumstances for a competitive dairy chain.

\section{S.2 Education and training of farmers is key to success}

Good education and vocational training is necessary to increase the competitiveness of milk production. This could be a good starting point for Dutch companies and education institutes to support the development of the dairy sector.

The knowledge level of farmers will improve through international exchange programmes for young farmers. Romanian farmers with international experience have the knowledge to develop their Romanian farm in a sustainable way. However, current farm structures with a large labour force per farm and uneducated labour hinder the uptake of vocational and theoretical training. 


\section{S.3 Knowledge transfer through practice-based training programmes}

Private companies active in dairy farming in Romania asked Wageningen Research to support them in the development of the dairy chain by organising knowledge transfer to farmers and advisors, especially in the central region of Transylvania, with a focus on family-sized farms. Therefore theoretical and vocational training programmes were conducted by Dutch experts in cooperation with milk processors and Dutch companies in Transylvania. The target group of these training programmes consisted of farmers and farm advisors in the region of Transylvania. 


\section{Samenvatting}

\section{S.1 Veel kansen voor zuivelproductie in Roemenië Romania}

In Transsylvanië zijn er voor gezinsbedrijven goede vooruitzichten voor de ontwikkeling naar een bedrijfsgrootte van 100 tot 200 melkkoeien en 200 tot 500 ha land. Hierbij zijn er verschillende strategieën mogelijk zoals specialisatie, samenwerking met andere bedrijven, diversificatie (zelf verzuivelen van melk, toerisme) en/of overgang van gangbaar naar biologisch. Door de geschiedenis van het land hebben coöperaties een negatief beeld. Nu worden er echter nieuwe en regionale coöperaties opgericht met jonge agrarische leden zouden die tot doel hebben om samen te werken op velerlei terreinen van machinegebruik tot afzet van producten.

De behoefte aan kennis en het gevoel van urgentie voor het verkrijgen van nieuwe kennis verschilt sterk. Er zijn jonge Roemeense melkveehouders die een periode in het buitenland hebben doorgebracht, en daarbij veel ervaring en inzicht hebben opgedaan in het reilen en zeilen van het melkveebedrijf. Deze kennis passen ze vervolgens toe op hun eigen bedrijf in Roemenië.

Internationale ervaring is dus zeer belangrijk voor het succes van het boerenbedrijf. Tijdens het project bleek dat er ook veehouders zijn die het nut van trainingen en kennis niet inzien, en dat zij moeilijk te overtuigen waren dat kennisontwikkeling ook een deel van hun werk zou kunnen zijn.

Gebleken is dat studiegroepen zeer moeilijk op te starten zijn in Roemenië. Voor de nieuwe generatie veehouders lijkt het dat studiegroepen wel een succes zouden kunnen worden.

Roemenië is een zuivelimporterend land, en de zelfvoorzieningsgraad voor melk en zuivelproducten neemt de laatste jaren af. Dit wordt vooral veroorzaakt door een afname van het aantal melkkoeien in eigen land en daarmee de eigen productie.

De kostprijs van melk is lager dan die in Nederland en vergelijkbaar met die van Polen. Vooral de kosten van grond en arbeid zijn laag. De gemiddelde melkprijs is echter ook lager in Roemenië. Dit kan worden verklaard door hogere ophaalkosten en lagere gehaltes in de melk. De omstandigheden lijken echter gunstig voor een sterke zuivelketen.

\section{S.2 Onderwijs en training van veehouders is belangrijke succesfactor}

Goed en praktijkgericht onderwijs is nodig om de concurrentiepositie van de melkproductie te verbeteren. Dit zou een goed uitgangspunt zijn voor Nederlandse bedrijfslevenpartijen om de ontwikkeling van de melkveehouderij in Roemenië te stimuleren. De huidige structuur op Roemeense melkveebedrijven met veel arbeidskrachten en laaggeschoolden remt op dit moment nog het effect van praktijkgerichte trainingen.

Het kennisniveau zou kunnen worden verbeterd door internationale uitwisselingsprogramma's tussen jonge veehouders te stimuleren. Veehouders in Roemenië met buitenlandervaring blijken goed melkveebedrijven te kunnen ontwikkelen. 


\section{S.3 Kennisoverdracht via praktijkgerichte trainingsprogramma's}

Nederlandse toeleverende en afnemende bedrijven hebben Wageningen Economic research gevraagd hun te ondersteunen bij de ontwikkeling van de zuivelketen in Transsylvanië met kennisontwikkeling bij veehouders en adviseurs. Deze kennis was vooral gericht op gezinsbedrijven met ontwikkelperspectief. In dit project zijn trainingsprogramma's opgezet en uitgevoerd door Nederlandse deskundigen in samenwerking met Roemeense verwerkers en Nederlandse partijen uit het bedrijfsleven in Roemenië. Doel was het verder ontwikkelen van de melkveehouderij en het verbeteren van de concurrentiepositie. In het programma zijn zowel veehouders getraind alsook adviseurs van melkverwerkers en andere adviesorganisaties. 


\section{$1 \quad$ Dairy industry in Romania}

\section{$1.1 \quad$ Background}

\section{Structure of the sector}

In Romania 1,190,000 dairy cows are kept on 604,000 dairy farms, resulting in an average herd size of 2.4 cows per farm. Eighty-four per cent of these holdings have 1-2 cows per holding and can be considered as backyard farms. On average the annual production is approximately 2,500 litres per cow. Only $25 \%$ per cent of the milk produced is delivered to processing industry; the remaining part is either used for on-farm consumption or direct sales. 935.000 million tonnes of milk is delivered to dairies where it is mainly processed to dairy products. ${ }^{1}$

To provide sufficient dairy products, substantial import of both milk and dairy products is needed. About one third of the dairy products consumed are imported. The processing industry faces serious challenges with respect to processing, milk quality and logistics, both from farm to processing plant as well as transport to the urban areas. There is a large potential for growth of the Romanian dairy sector including processing industry due to the present high level of import as well as the foreseen switch from artisanal dairy to packaged dairy. ${ }^{2}$

\section{Domestic support}

The government actively supports the development of dairy farms. For example, in 2016 the following support was implemented to support production and enlargement of the dairy industry:

- A programme to support dairy farm enlargement of approximately $€ 420$ per million tonnes of milk delivered in case more than 3 million tonnes were delivered per farm.

- Coupled support to dairy farmers of approximately $€ 900$ per head.

- Decoupled support of approximately $€ 100$ per head.

- Support for the acquisition of heifers of $€ 1.000$ per head using the minimis regulation. ${ }^{3}$

\section{This project}

Romanian milk producers are confronted with increased competition among farms both at national and international level. To be able to cope with challenges like low production costs or high milk quality, dairy farmers need to increase their knowledge, training and modern production technologies. ${ }^{4}$ This project aims to contribute to this.

This project is a PPP (Public Private Partnership), part of a large Research \& Development Programme, and is of importance due to stimulate export of knowledge and technology. The programme is financed by the project partners and by the Dutch government (Ministry of Economic Affairs).

The partners in the project are:

- Lely Industries (Robotic milking system, farm and forage harvesting equipment)

- FrieslandCampina Romania

- Agri Beerepoot (Animal housing systems)

- Mueller (Milk cooling techniques)

- Uniform Agri (management software systems)

- Agriworks (Dairy consultancy)

- Wageningen University \& Research.

1 http://eda.euromilk.org/fileadmin/user_upload/Public_Documents/Dairy_Focus/Dairy_Focus_Romania_2019.pdf

2 Stanciu, S.T. Romanian Milk market Analysis. SEA - Practical Applications of Science. Volume II, Issue 2 (4)/2014. The Bucharest University of Economic Studies, Romania.

3 Commission Regulation (EU) No 1407/2013 of 18 December 2013 on the application of Articles 107 and 108 of the Treaty on the Functioning of the European Union to de minimis aid Text with EEA relevance https://eur-lex.europa.eu/legalcontent/EN/TXT/? uri=CELEX\%3A32013R1407

4 A. Popescu, 2017, Trends in milk market and milk crisis impact in Romania, Scientific paper series management, economic engineering in agriculture and rural development, Vol, 17, issue 2. 
Besides these partners there is involvement of the Embassy of The Netherlands in Bucharest (agricultural counsellor), and the Romanian Ministry of Agriculture and Rural Development.

The project took place in the region of Transylvania with the processors FrieslandCapina Romania and Covalact present. Transylvania is a mountainous region with smaller-sized family farms. The main agricultural activities are forestry, dairy, sheep and goat farming.

The project started with an inventory of operational and tactical management of 24 dairy farms in this region. The outcome was that a better operational management of farmers could improve farm results, cost price of milk and the quality of milk, and that the milk processors could have a very important role in advising the farmers. It seemed to be very important to increase the knowledge of farmers and advisors of practical aspects as quality of feed and feeding, fertility rate and calving period, young stock management, hoof trimming, animal housing, milking and milk hygiene, labour management etc. To increase the knowledge of farmers a scheme aiming at Romanian professional family farms was developed by Wageningen Economic Research in collaboration with project partners. This scheme consisted of individual advice to farmers, theoretic and vocational training of farmers and advisors, workshops and study groups. The ultimate target group of the project and project partners are the approximately 5,000 Romanian family farms with 20-150 dairy cows. These farms have taken the first steps to produce more milk and have the potential to develop to a more efficient milk production. For the project partners this target group is of interest due to the need of knowledge and technology.

\subsection{Objective of the study}

The objective of this project is to contribute to the development of a competitive dairy value chain in Romania. A value chain characterised by professional family farms (20-150 dairy cows), a competitive cost price of milk and ecological and economical sustainable farming practice. The milk quality produced on these farms should be produced according to international food safety standards. Milk produced is then delivered to processors in which it is processed in to quality products with high added value.

The project is a research and development project. The development part consists of the following elements:

- development of farms and development of knowledge of farmers

- training of advisors

- linking of the project with other relevant stakeholders (University, banks, etc.).

The research part of the project consists of:

- gaining insights into the information needs of farmers, success and fail factors

- development of entrepreneurial training of advisors and farmers

- monitoring and evaluation, lessons learned.

The project started in 2015 and was finalised in 2019.

\subsection{Structure of this report}

Chapter 2 analyses the current dairy sector and milk market in Romania and explains the reasons for the base of the project and the importance of developing the dairy chain in Romania. Chapter 3 describes the underlying base of the role of study groups and the importance of strategic management.

Chapter 4 provides a description of the activities of the project (knowledge exchange) with the relevant stakeholders. Finally, in Chapter 5 a discussion of the experiences and lessons learnt is given and this chapter ends with conclusions and recommendations. 


\section{Milk production and milk market in Romania}

This chapter describes the developments of the milk production and the milk market in Romania in the past and in the future. These developments combined with the knowledge of the project participants have led to a SWOT analysis of the dairy chain in Romania. This SWOT has given direction to the structure and activities of the project.

\section{$2.1 \quad$ Trade}

Since Romania entered the EU in 2007, import and (to a lesser extent export) of dairy products increased substantially. Import of dairy products increased from $€ 45 \mathrm{~m}$ in 2006 to $€ 417 \mathrm{~m}$ in 2017 Export increased from $€ 16 \mathrm{~m}$ to $€ 107 \mathrm{~m}$ in 2017 . The trade deficit increased substantially and the selfsufficiency rate of Romania for dairy products decreased. The main reason is the reduction in domestic production due to a decrease in the total number of dairy cows and the number of farms with dairy cows.

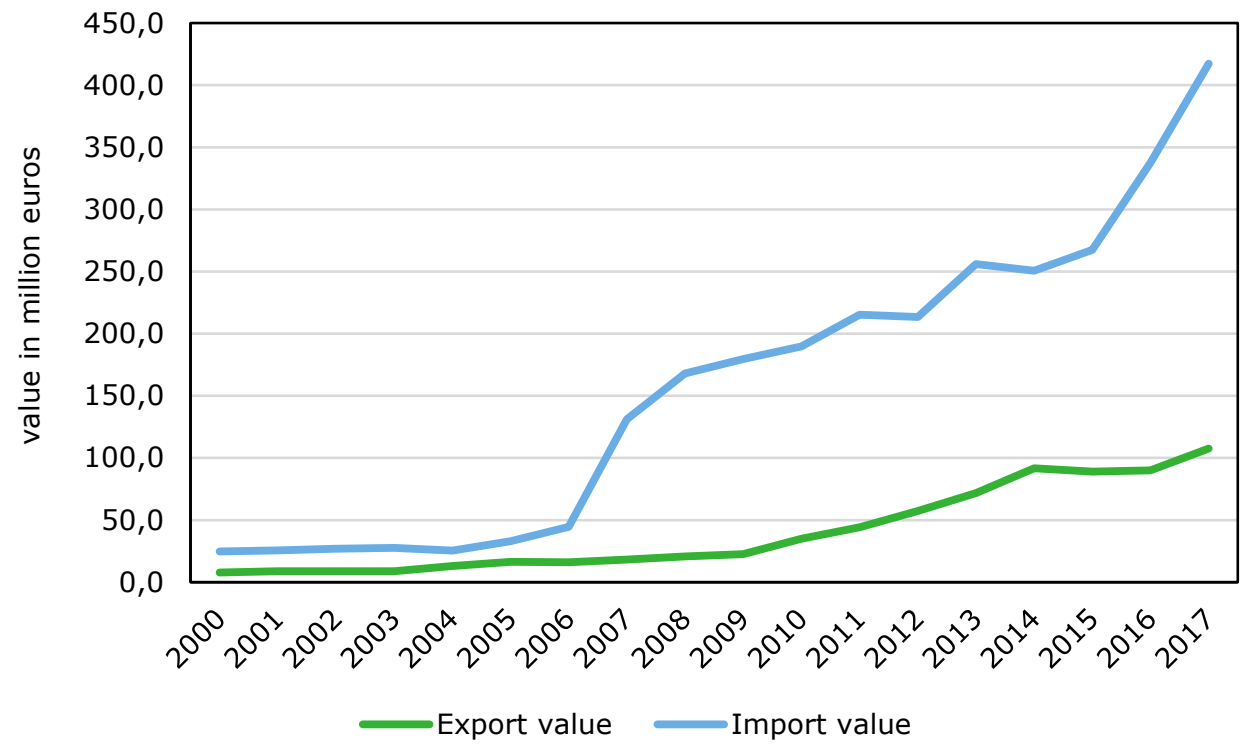

Figure 2.1 Import and export value of dairy products in the EU 

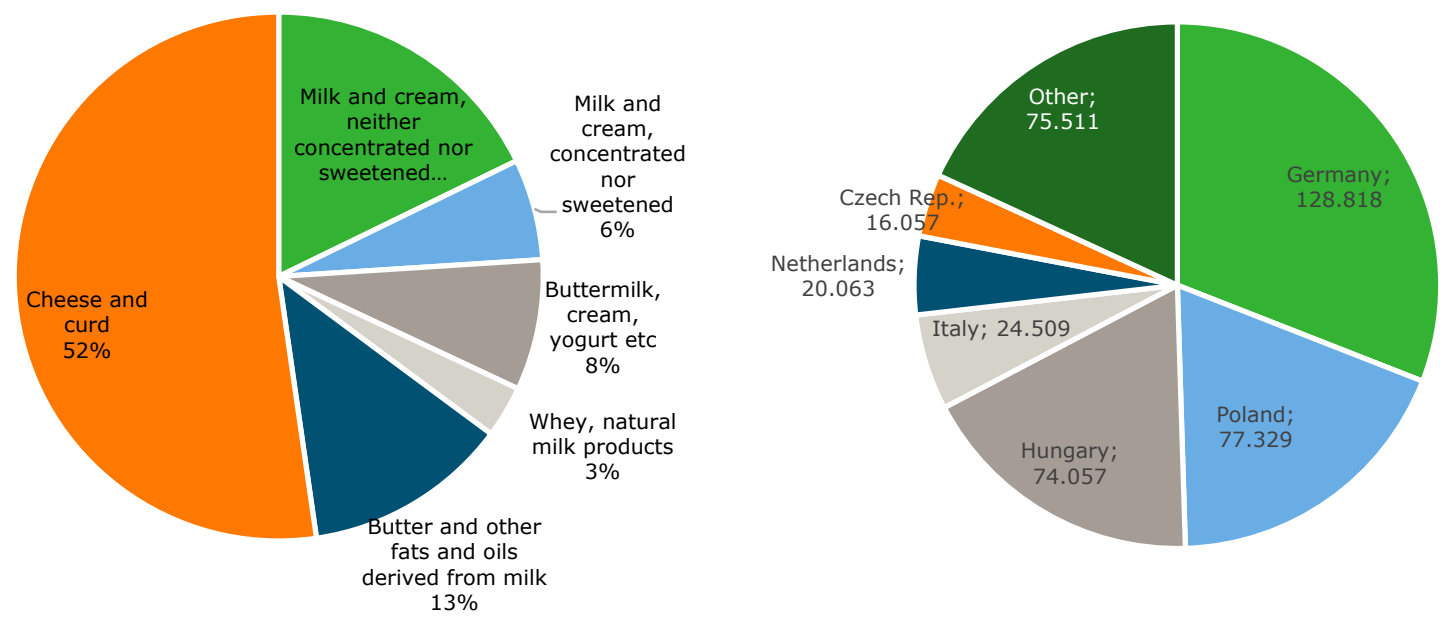

Figure 2.2 Import in Romania of dairy products: Type of product (\%) and country of origin (in '000 €) (2017)

Source: Comtrade.

Cheese and curd is the most imported dairy product ( $44 \%$ of the value). However, also substantial amounts of milk and cream are imported. Besides processed milk also raw milk is imported to fil deficiencies in Romanian dairies (Popescu, 2017). The main origin of the imported product is Germany, Poland and Hungary. Sixty-seven per cent of the imported product originates from these countries.

Export of dairy products has increased during recent years. Main destinations are Greece, Bulgaria and Hungary (65\% of the export). The main product exported is cheese which accounts for approximately $30 \%$ of the export value.

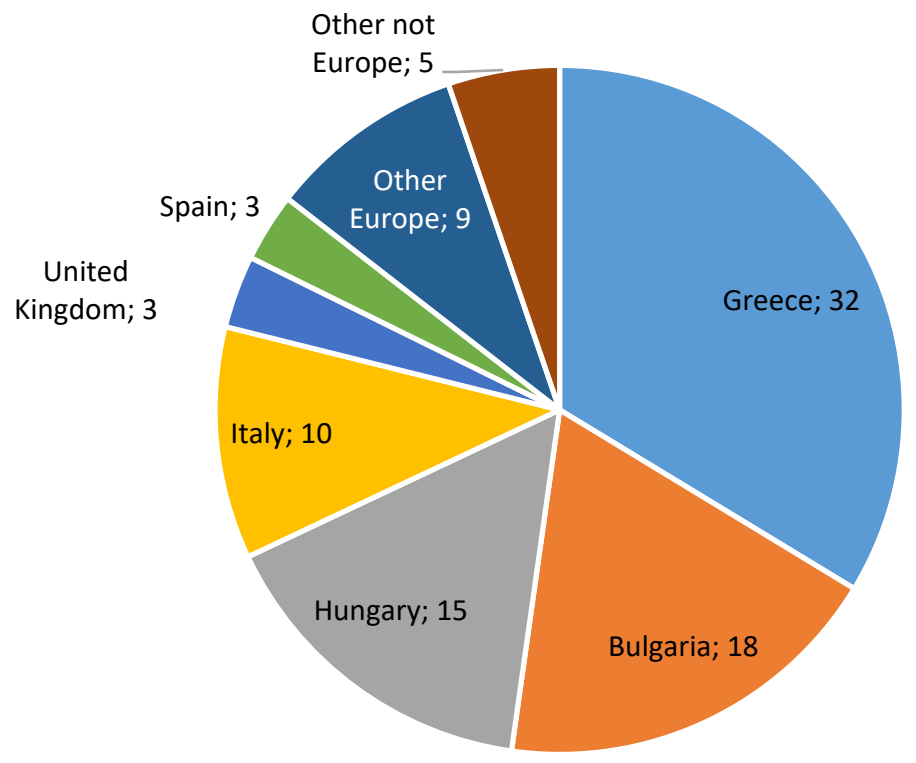

Figure 2.3 Main export destinations for dairy product export (in million $€$ ) Source: Comtrade. 


\subsection{Primary production}

The Romanian dairy industry is characterised by a large number of small farms (Figure 2.4). In 2016, $95 \%$ of the farms have fewer than 10 cows. On these small farms $74 \%$ of the dairy cows are kept. The target group of this project, farms that have between 20 and 100 cows, consists of 6,700 farms $(1,4 \%)$. As can be seen from Figure 2.5 most of these target farms are located in the centre part of Romania (Centru: 41,4\%). On these farms average production per dairy cow is around 3,500 kg per cow per year.

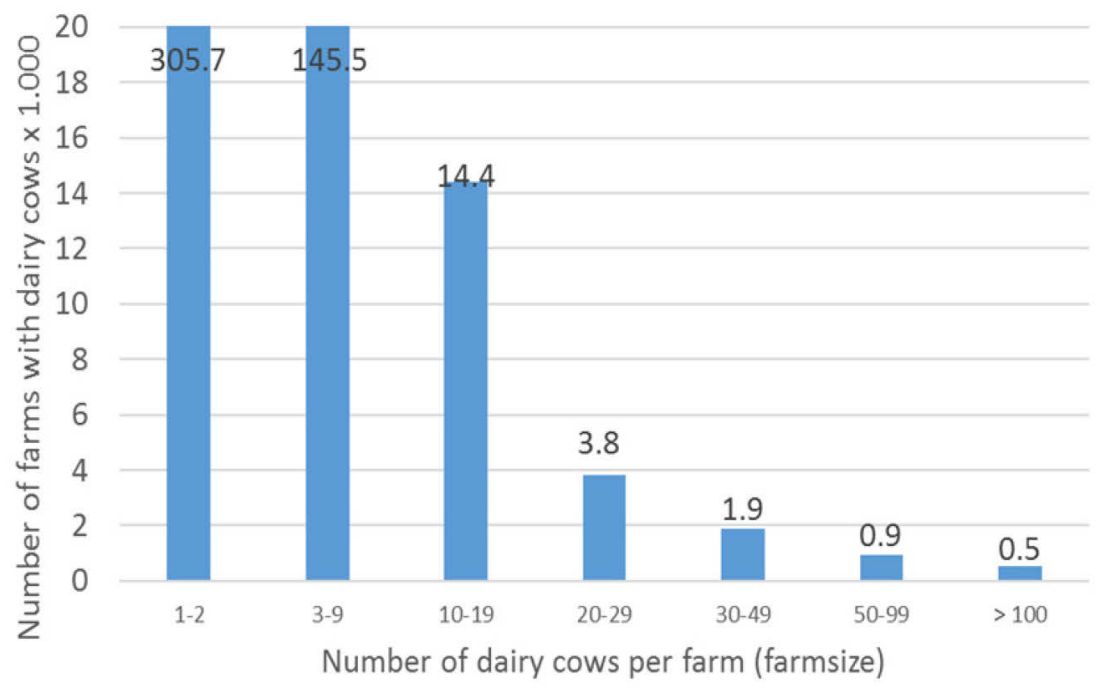

Figure 2.4 Farm size in Romania (2016)

Source: Eurostat.

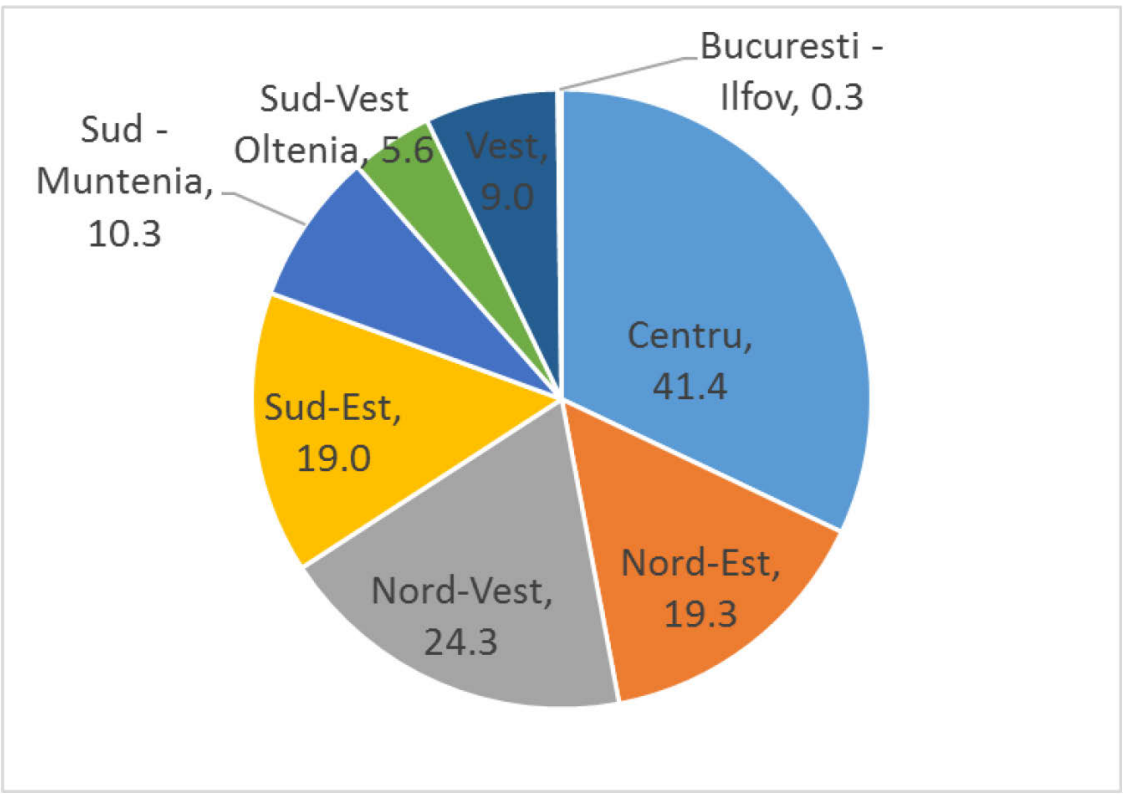

Figure 2.5 Percentage of farms in several regions of Romania with a herd size between 20-100 dairy cows 


\section{Revenues and costs}

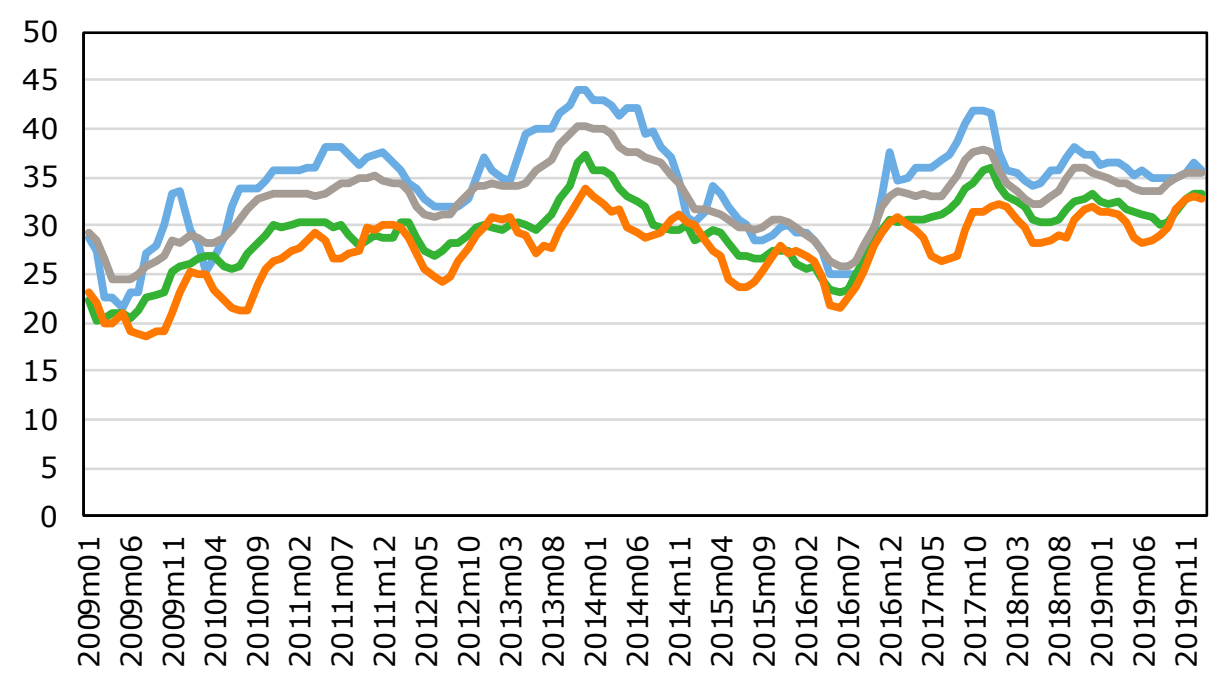

Netherlands Poland $\longrightarrow$ Romania $\longrightarrow$ EU

Figure 2.6 Development of the raw milk price in eurocents per litre in Romania in comparison with the EU and benchmark countries

Source: Eurostat.

As Figure 2.6 shows, Romanian raw milk price although following the price developments in the rest of the EU is lower than benchmark countries and the EU average. The reasons for these average lower prices are (Popescu, 2017):

- Logistic challenges: large distances to dairy plants

- Large regional differences in milk price

- Mostly small volumes to be collected per farm

- Quality of the milk (e.g. fat and protein content).

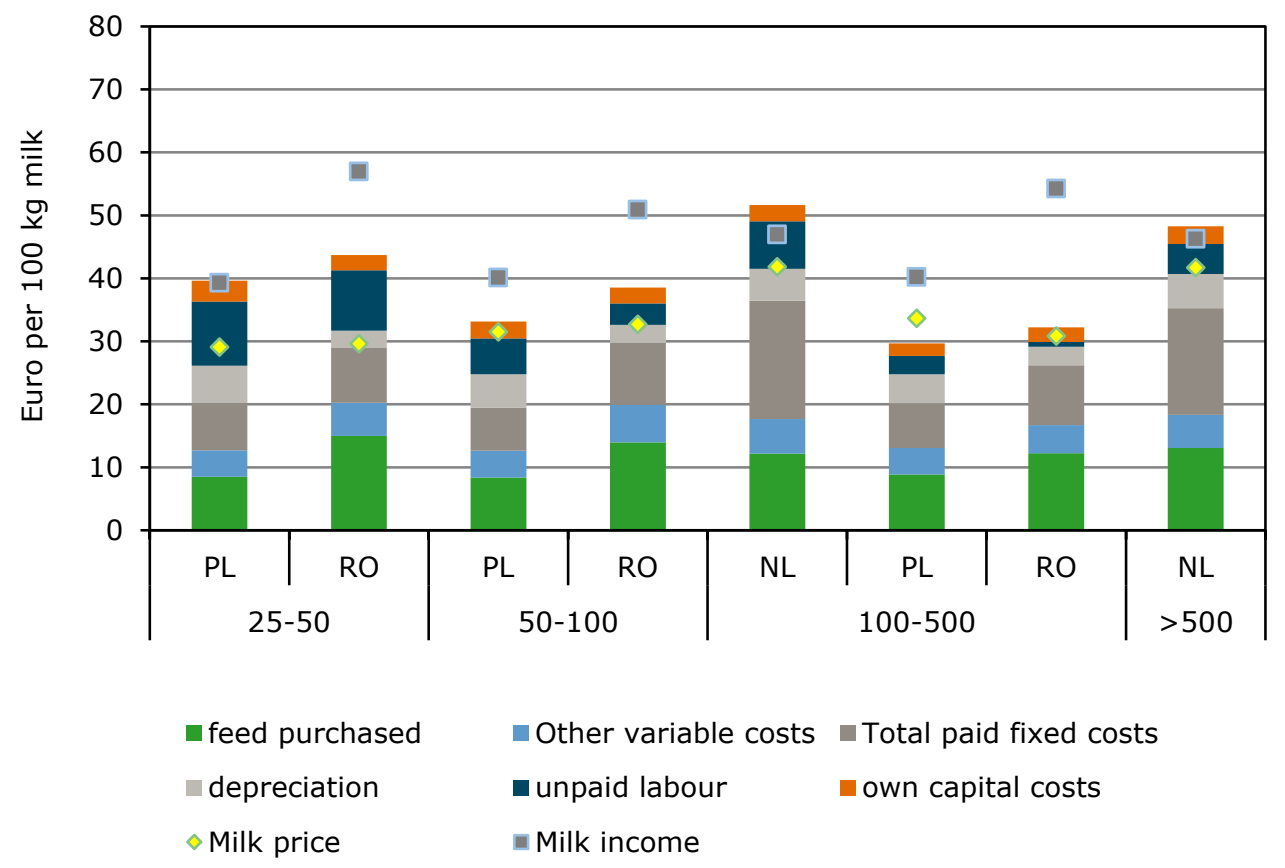

Figure 2.7 Production costs in $€$ per $100 \mathrm{~kg}$ of milk in 2017 on specialised farms and different size classes (1,000 SO), in Romania (RO) in comparison with Poland (PO) and the Netherlands (NL) Source: FADN. 
Production costs of both farms with 20-50 cows and with 50-100 cows are higher than the costs at comparable farms in Poland. However, they are lower than in the Netherlands (Figure 2.7). The reason for this is that in the Netherlands fixed costs (farming overheads/external factors) are higher than both in Romania and Poland. The difference between Romania and Poland is mainly due to the higher feed costs in Romania. On average it seems that the cost price of milk in Romania is low compared to the Netherlands but at the same competitive level as in Poland.

\subsection{Foreseen developments}

In the following 3 figures the current development and expected development of the average yield per cow, number of dairy herds and milk price in Romania are presented. Current numbers are up to 2017 based on Eurostat and expected numbers are based on estimates of a dairy market outlook on agrifood projections using Agmemod (see textbox).

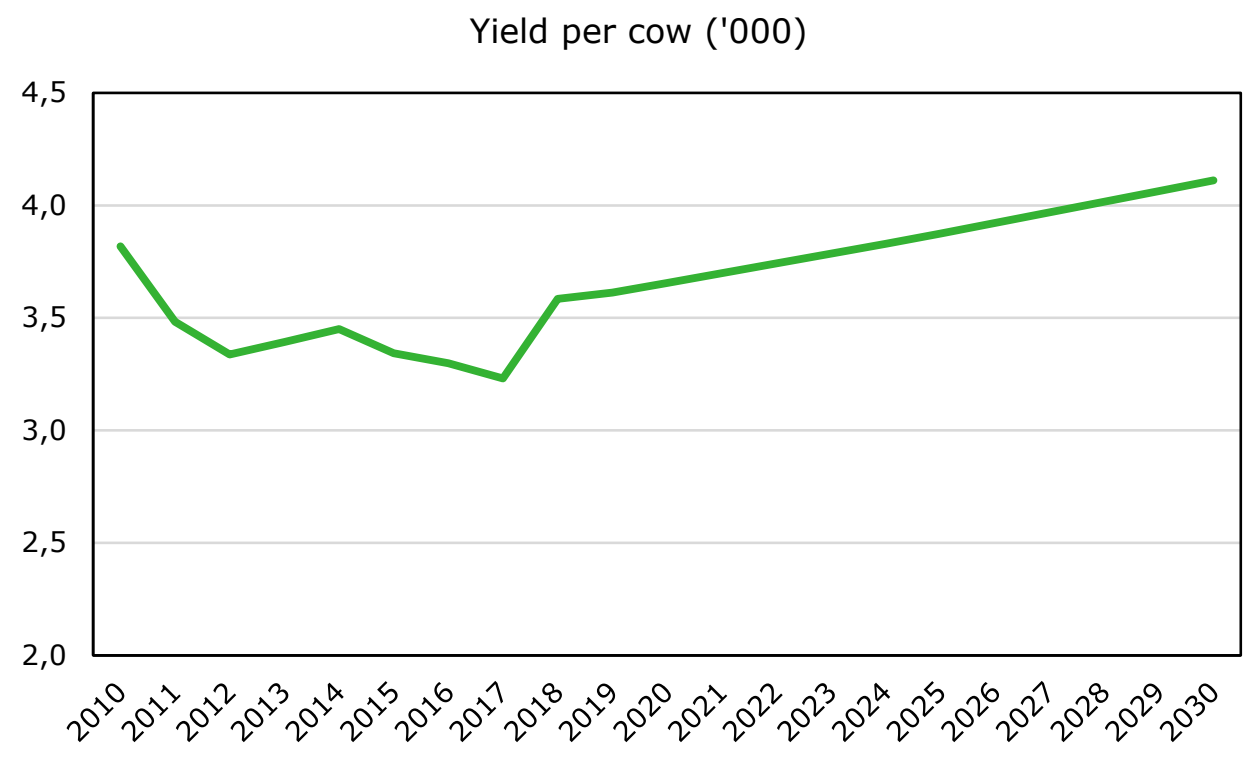

Number of dairy cows

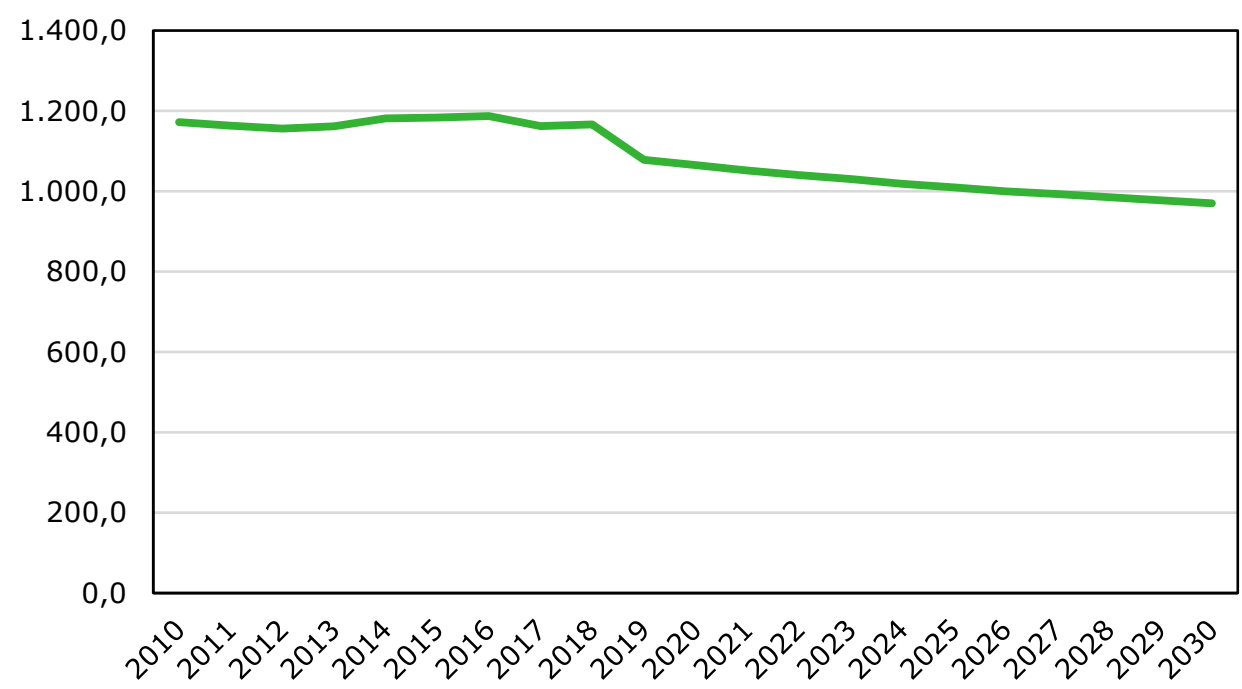

Figure 2.8 Yield per cow and number of dairy cows (in '000) in Romania in the period 2010-2017 (actual and 2017-2030 projected) 


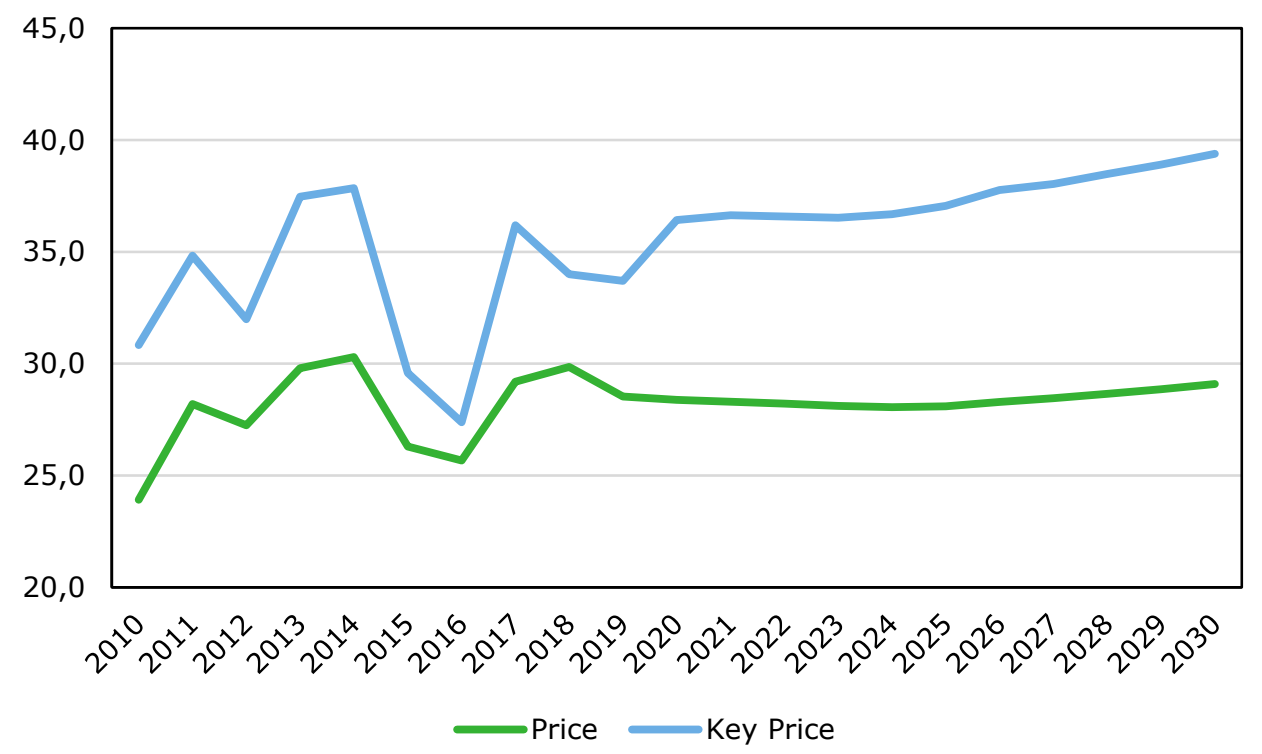

Figure 2.9 Current and expected milk price in eurocent per litre compared to the EU key price in Romania in the period 2010-2019 (actual and 2020-2030 projected)

As can be seen from Figure 2.8, the production per cow is expected to increase and the number of cows is going to decrease. Both effects are due to the expected decline in the number of small-scale farms in Romania. As can be seen from Figure 2.9, the fluctuations in the milk price are expected to be limited with a gradual increase in the EU key price in the period 2017 to 2030 . The increase in the Romanian milk price is less than in the EU Key price and the gap is becoming wider. The mean reason for the increasing gap is the increasing difference in farm size between Romania and the rest of the EU.

It should be noted that more than in the rest of the EU, differences in production, size and price between farms are expected to be substantial.

\section{Textbox Agmemod}

To give a general overview of the dairy sector in Romania, in terms of production numbers, volumes, trade, and general trends, national potential for dairy production is assessed with an available modelling tool. Wageningen Economic Research hosts the development of the model called AGMEMOD (Agricultural Memberstate Model). The model covers European agricultural commodity markets. It is owned by a panEuropean network of economists working in the field of agricultural policy analysis.

AGMEMOD is a model that allows to make projections and simulations in order to evaluate measures, programmes and policies in agriculture at the European Union (EU28) level and the Member States level. The model is also used in various studies derived for the DG-Agri or JRC of the European Commission (AGMEMOD, 2016). The data source for the model is EUROSTAT and to some extent national statistics. 


\subsection{SWOT analysis of Dairy farming in Romania}

At the start of the project the project team made a SWOT analysis. This is presented in Table 2.1.

Table 2.1 Swot analysis of the Romanian dairy industry

\begin{tabular}{ll} 
STRENGTHS & WEAKNESSES \\
Low costs of land and labour & Small scale dairy farming \\
Low cost price of milk & High age of farmers, no successor \\
Family farms willing to develop & Land registration, cadastre \\
Presence of milk processors & Knowledge and skills of labour \\
Good mentality of farmers who want to grow & Milk quality and milk yield \\
& Knowledge system (education, extension, technical \\
& knowledge) \\
& Lack of entrepreneurship \\
& Financing opportunities and lack of trust by banks \\
OPPORTUNITIES & THREATS \\
High natural potential for milk and roughage production & Too many rules lead to delay in decision taking \\
Low fertiliser and chemical use: potential for organic milk & Lack of cooperation mentality \\
Growing market for organic milk & Low standard of living in rural areas \\
Rural Development Program: & Abolition of milk quota \\
- Fostering knowledge transfer & Too much focus of policy on rural development instead of \\
- Enhancing farm competitiveness & agricultural development \\
- Promoting food chain organisation & Competition with other agricultural activities \\
Interest of foreign business partners to invest & \\
Large domestic market & \\
Availability of dairy processors & \\
\hline
\end{tabular}

The following additional remarks can be made:

- The number of backyard farms is declining, but the political climate is cautious and in favour of backyard farms (due to a large number of voters).

- There is cheap land available but it is often multiple owned and difficult to have long term lease or purchase contract.

- Labour and quality of labour is a problem. Working in rural areas is not seen as attractive. Labour force for qualified labour is affected due to diaspora. Student exchange can contribute to making the rural areas more attractive.

- One of the Dutch partners found out that partly robotising could solve the attractiveness and labour quality problem. The milking robot could be very interesting for family farms due to the relatively low investment.

- There is a land climate with large variation in rainfall between regions. In Transylvania the region is mountainous with only possibilities for grass, cows, sheep and goats.

This analysis shows that Romania provides development opportunities for the dairy industry for the development of:

- Family farms

- Milking robot farms

- Organic production

\subsection{Conclusion and possible implications}

The aim of the project Dairy Chain Development is to improve the competitiveness of milk production in the region of Transylvania by Dutch knowledge and technology. Based on the results of the SWOTanalysis the project has focused on (a) family-sized farms and (b) has paid special attention to knowledge exchange to farmers and farm advisors. The milk processors play a central role due to their relation with the farmers. Knowledge exchange will occur by trainings and train the trainer sessions, 
and later on by forming study groups. Aim is to improve the milk quality and efficiency. The conventional farmers are the first target group, followed by organic farmers or farmers in transition to organic farming.

Robot milking can be seen as a solution for family sized farms to solve their milking labour problems. Therefore the project will pay special attention in the region to farmers who are willing to change to robot milking and have the opportunities to find the funds to invest. 


\section{Implementing a training programme}

In knowledge dissemination projects study groups could play an important role in the transfer of knowledge and experiences both between facilitator/expert and farmers and amongst farmers. To analyse the situation of each farm the ISM approach is used for several years in similar projects both in the Netherlands as in other countries. ${ }^{5}$

This section gives some background information on the role that study groups can play in improving the competencies of farmers and provides some background information on ISM.

\subsection{The role of study groups}

\section{Study groups}

The training programmes aim to improve the participants' dairy farming competencies using a study group. Competencies are defined as the ability to perform specific tasks. They are the underlying knowledge, skills, abilities, personality traits, and know-how that result in effective task fulfilment. An impression of a person's competencies is given by the observed behaviour either in a natural or artificial environment. Competencies are changeable and learnable, allowing intervention in terms of the selection and teaching.

Learning in study groups is a means of proactive informal education that seeks to assist individuals to better understand their situation. ${ }^{6}$ In agriculture, study groups are important for acquiring and spreading information, and as a form of learning based on low costs. Agricultural study groups have proven to be effective in the sense that these groups enhance collective learning by providing space for members to follow their own rhythm and dynamics in learning. Individual farmers usually possess much expertise - based on experience, on-farm experimentation, and/or training - which could be relevant to other farmers. Intrinsically, much of the knowledge that farmers possess is of a tacit nature. In their single-person business, besides their own experience, external contacts are the only means that farmers have of acquiring tacit knowledge. Therefore, study groups are an ideal opportunity for farmers to learn, since pooling farmers in study groups leads to an easier spread of tacit knowledge.

\section{Role of the facilitator}

For the learning process in study groups to be effective, the role of the facilitator is crucial. The facilitator has a threefold task: 1) to facilitate the group process, 2) to teach, and 3) to be an expert on technical aspects of farming. He has to have communicative skills as well as specific knowledge of the subject at hand. The facilitator brings people together (networking) and acts as a catalyst, and/or directs processes of learning and exchange, either in general or focusing on a specific problem. The main task is to empower the participant and to support the peer teaching process. To enable this process, a facilitator has to effectively manage the group process and select the extension paradigm that is most effective in supporting learning of the participants. Recognition of the different learning styles of the participants and having an open eye for implicit learning will make this challenging task easier. ${ }^{7}$

\footnotetext{
5 A. Kuipers, Verbic, M., Glavac, J., Kos-Skubic, M. \& Klopcic, M. (eds.)., 2010, Producers and consumers' choices regarding cattle farming systems and products: surveys in Slovenia. Ljubljana, Slovenia: Ministry of Agriculture, Forestry and Food (MAFF), p. 31-42 300 p.

6 J.A. (Coutts 1994) Process, Paper Policy and Practice: A Case Study of the Introduction of a Formal Extension Policy in Queensland, Australia 1987-1994. PhD thesis, Wageningen University.

7 Based on: Bergevoet, R. H. M. and C. V. Woerkum (2006). "Improving the Entrepreneurial Competencies of Dutch Dairy Farmers through the Use of Study Groups." The Journal of Agricultural Education and Extension 12(1): 25-39.
} 


\section{Importance of relevant peers and partners}

The role of the partners and peers is to support the project with knowledge and technology on specific elements. A peer advisory group is in essence an information exchange established for the sake of mutual self-improvement-all members give, as well as take. In which everyone actively participates. ${ }^{8}$

Measuring effectiveness of on-farm demonstration activities is challenging since they are relatively small-scale and short-lived and in a situation of limited resources. The concept of peer learning between farmers suggests a two-way (or more), reciprocal learning experience. One can be more knowledgeable on a certain topic, but can still learn through explaining, listening, discussing and working together with the other, who might be more knowledgeable on another topic. ${ }^{9}$

\subsection{Development of entrepreneurship}

\section{The ISM method ${ }^{10}$}

Agricultural producers, focused on operational decisions taken on a day-to-day basis often do not see the need for a vision for their enterprise in a long-term, strategic perspective. This is even more the case with farmers in less favourable rural areas, in general with small-scaled farms. Building a future in such areas requires a certain level of entrepreneurial competencies (Malak-Rawlikowska et al., 2018).

Therefore, training in entrepreneurial behaviour and decision making is essential, as are tools to support such trainings. Wageningen Economic Research in the Netherlands has developed the Interactive Strategic Management method (ISM) based on the theory of strategic management.

The ISM method has three main principles:

1. Emphasis is on the entrepreneur. Placing the entrepreneur (in this case: the farmer) at the centre of the attention means recognising that, instead of an advisor, the farmer himself is responsible for the content of the strategic plan for his farm. An advisor or, rather, facilitator is only there to guide and stimulate the process. The focus in the ISM training is on strategic choices (3-10 years ahead). This means that tactical choices (choices for the next 1-2 years) and operational issues do not receive much attention.

2. Interaction with the environment. There is not only a lot of attention during the training sessions about presenting and discussing ideas and views among the participants. Farmers are also challenged, not only during the training but as a basic principle of entrepreneurship, to communicate with one's partner, parents, children, advisors, industry agents etc. and with citizens and customers.

3. Focus on actual progress or actions of the entrepreneur. To be successful, an entrepreneur needs to translate ideas into concrete and smart action plans, which he evaluates on a regular basis.

An ISM training is guided by a facilitator.

\footnotetext{
8 K. Doerr, 2012, Peer Advisory Groups in Agriculture: A Resource Guide http://agecon2.tamu.edu/people/faculty/klinefelter-danny/Selected\%20Articles/Kayla\%20Doerr\%20$\% 20$ Peer\%20Advisory\%20Groups.pdf

9 Hanne Cooreman et al., Development process of a conceptual framework to investigate the role of peer learning processes at on-farm demonstrations in the light of sustainable agriculture, 13th European IFSA Symposium, 1-5 July 2018, Chania (Greece), http://ifsa.boku.ac.at/cms/fileadmin/Proceeding2018/1_Cooreman.pdf

${ }^{10} \mathrm{An}$ introduction to the background, principles and application of interactive strategic management can be found in annex 2. This section only briefly describes the outcome of the two workshops in September 2019.
} 


\section{$4 \quad$ The project}

\subsection{Participants}

The project focused on family-based dairy farms in Transylvania. Transylvania is a mountainous region suitable for dairy, sheep and goat breeding, forestry and has less arable farming. In Transylvania FrieslandCampina Romania is present with 2 milk processing factories.

With support from FrieslandCampina and - in the beginning of the project - milk processor Covalact, in 201516 farms have been visited and analysed in the region of Cluj, Covasna, Bihor and Mures. These farms were representative for family farms in this region and have already taken a small step in the development to more specialised dairy farming. Participating farmers were eager to learn and develop their knowledge towards better farm management. During the selection of these farms the starting situation has been captured. Since the start of the program there have been changes in the farms participating in the project, some of them dropped out since then, for different reasons, and other farms came in. As Covalact decided in June 2016 not to continue with the project their farms have been dropped out as well. At the end of the project 3 pilot farms participating from the beginning were left, as several other farms entered the project until now.

In 2016 several eco farms were added to the project. Project partner Lely added 6 farms with milking robots to the project. All farms can be characterised as family farms with between 30 and 200 dairy cows and between 100 and 1,000 ha of land. Figure 4.1 gives an overview of the location of the several farms. In total 22 farms participated in the project but composition of the group varied during the project.

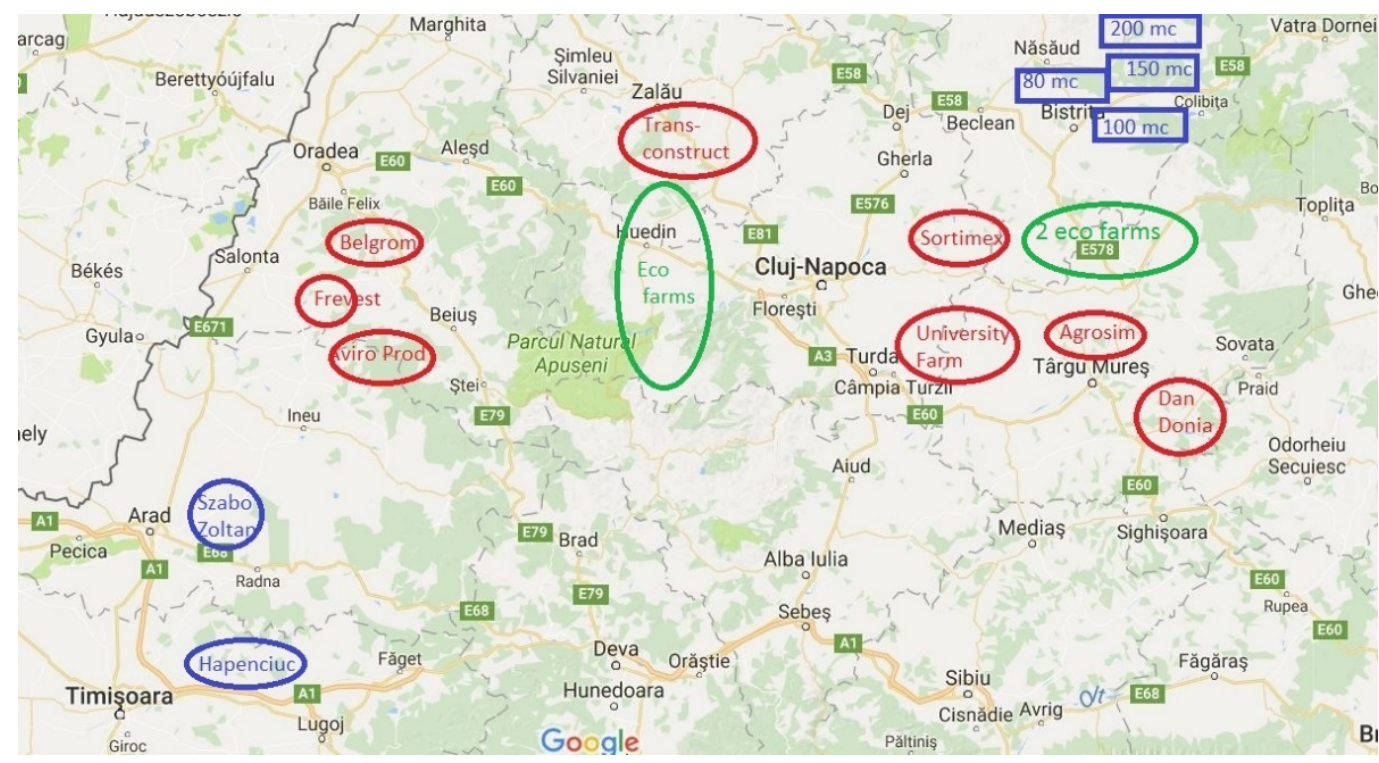

Figure 4.1 Location of the farms of the participants in the project (red: conventional farms; green: eco farms; blue: robot farms) 


\subsection{Project description}

After the first selection of the 16 farms an analysis was made of the needs in relation to the goals of the project. This lead to the conclusion that a better operational management of farmers could improve farm results and income, cost price of milk and the quality of milk. It seemed to be very important to increase the knowledge of farmers and advisors of practical aspects:

- Quality of feed and feeding

- Fertility rate and calving period

- Young stock management

- Hoof trimming

- Animal housing

- Milking and milk hygiene

- Labour management.

To increase the knowledge of farmers and farmers' advisors during the project the following activities were conducted:

- Training

- Theoretical and vocational training of advisors (train the trainer)

- Theoretical and vocational training of farmers

- Individual advice to farmers

- Study groups

- Workshops and demonstrations

- Interactive Strategic Management (IMS) workshops

- Agricultural education: students involvement and participation in the Borderless Network Romania.

\section{Trainings}

Most of the trainings and workshops were carried out at the FrieslandCampina pilot farms. In exceptional cases trainings or demonstrations were carried out at other farms where other partners were active (Lely CRV genetics).

In all activities the staff of FrieslandCampina and if necessary other project partners were involved. Staff of FrieslandCampina Romania (FCR) was willing to be trained as farm advisor. Mostly the trainings were organised by the staff of FCR. They also invited other farmers, veterinarians, professors and teachers of the Agricultural University of Cluj and other advisors (Transylvanian Bank, feed advisors). The training sessions were conducted by Dutch experts and specialists.

The staff of FCR has visited the Netherlands during one week. During this period they had a programme with trainings and visits to demonstration farms, experimental stations and the headquarter of FrieslandCampina. Special attention was paid to the forming of study groups of farmers and communication with study groups.

\section{Individual advice to farmers}

Staff of FCR and other advisors were trained to give individual advice to farmers to support the farm development. During the time that the Dutch experts were present in Romania they visited the pilot farms and gave individual advice, in the presence of the regular farm advisors. Beside Dutch students from Universities of Applied Sciences in the Netherlands had farm visits together with Romania students, analysed the farm results and discussed their farm analysis together with farmer and farm advisor.

\section{Study groups}

After one year it was foreseen for FrieslandCampina Romania to set up study groups of farmers. It seemed very difficult to organise study groups of dairy farmers in Transylvania. Farmers didn't attend due to lack of time, travelling distances and maybe lack of interest. Romanian farmers are not used to cooperate and there is a lot of distrust. Later on Lely started a study group of farmers who started a milking robot. These farmers exchanged a lot of experiences about the robot and learned a lot of each other (pers. communication of farmer Bistrita). 


\section{Workshops and demonstrations}

During the project several workshops and demonstrations were organised. The workshops and demonstrations were led by Dutch experts or representatives of Dutch companies. Farmers, feed advisors, veterinarians, financial experts, universities and students were invited. The scope of the subjects was very broad, from practical daily animal management, grassland management, feed management, grass and maize breeds, robot milking, All these activities were organised at farm level.

\section{Interactive Strategic Management in Romania}

In September 2019 two workshops were organised in cooperation with the Agricultural Universities and carried out on the theme of 'Interactive Strategic Management' (ISM) with the slogan 'Farming with vision': ${ }^{11}$

- Cluj: University of Agricultural Sciences and Veterinary Medicine Cluj-Napoca (USAMV Cluj) with 26 participants

- Bucharest: University of Agronomic Sciences and Veterinary Medicine of Bucharest with 24 participants.

In Cluj, three presentations were given on the following farms:

- Organic holding: Silvania Organic Farms Agricultural Cooperative

- Somes Aries Cooperativa Agricola

- Start-up Atelierul de Lapte.

In Bucharest, a presentation was given by Ion Militaru (Agroserv Maruta (farm of Nicusor Serban), PhD USAMV), including the dairy factory that was run by the daughter and son-in-law of the farmer.

The ISM concept was presented by Wageningen Economic research (Bert Smit) and was generally accepted as a way to improve Romanian farms, their structure and their performance. Based on the outcomes of the workshop it was proposed to have:

1. a three-day training, in which the all the aspects related to strategic planning receive attention;

2. ISM to be adapted to become well understandable by Eastern-European farmers. ${ }^{12}$

At the end of 20197 project farmers ( 3 organic, 3 conventional, one with milking robot) were interviewed with focus on strategic development. Questions were structured around the three E's: Entrepreneur, Enterprise and Environment. The interviewed farmers showed a lot of interest in this approach. Results are presented at a seminar about Family Farms (INDAGRA, November 2019) and described in Appendix 2.

\section{Agricultural education: students involvement and Borderless Network Romania}

Students of the EARES University of Applied Science Dronten and van Hall Larenstein University of Applied Sciences Leeuwarden were involved in the project in cooperation with students from the University of Agricultural Sciences and Veterinary Medicine Cluj-Napoca. Together they planned farm visits at the pilot farms and analysed the operational and tactical farm characteristics, sometimes with special focus on farm activities, e.g. young cattle, roughage quality. During a second visit they discussed the results with farmer and advisor.

The Borderless Network Romania is a cooperation of Dutch agricultural schools with a focus on Romania. This network coordinates Dutch education activities in Romania and is looking for opportunities to play a larger role in the Romanian agricultural education system.

There is little high-qualified agricultural labour available in Romania. Most managers of larger farms have a university education, mostly from the agricultural or technical universities. In addition, these managers often experienced a few years abroad before coming back and starting a farm.

The agricultural high schools and colleges are less popular. Lack of money and lack of interest from younger people are leading to fewer numbers of students. The coming years European funds will be available to give these institutes incentives.

\footnotetext{
${ }^{11}$ The report of the workshop is in Appendix 6.

${ }^{12}$ As done in an ISM process with Erasmus-partners from Poland, Lithuania, Slovenia, Austria and Sweden.
} 


\subsection{Learnings of the participants}

To get an insight into the learnings of 9 participating farmers in the project a telephone survey was organised based on a semi-structured interview scheme. These interviews were focused on the insights of the farmers and the ways they had changed their management at the farm due to these insights. The interviews were conducted in February 2018.

In October 20197 farmers were interviewed with a focus on the strategic management. The results are presented in Appendix 3. Some of these farmers made some remarks about the training programme. The main findings of the farmers are presented below.

\section{Usefulness of the trainings}

All people interviewed indicated the trainings were useful.

'It was a positive experience, from which I learned a lot of practical things. It's a different situation when someone tells you something and another thing when they show you on the farm. It was possible to ask practical questions, referring to the living animal and not hypothetical situation. There were many benefits that we had from trainings, from each one we learn something, both from the trainer's experience and the fact that more farmers were together, learning from each other's experience.'

'It was a positive experience that brought added value to our farm through the provided knowledge. The actions of the project have pleased our expectations, some things have been explained to us better, things which we knew, but in other ways. At the training programmes had been exposed practical things and they can be implemented more easily at the farm level.'

\section{Effective learning transferred into practice}

The practicality of the training was well appreciated.

'We have learned new things, and examples would be: establishing feed digestibility, animal classification, and animal rules. On our farm I had a problem, for example, that the animals were too fat and we tried to change feed, lowering the fat on the farm talking about the animal's body, resulting a larger the animal reproducibility rate. Following the participation in the training programmes, certain management principles have been changed, which are related to the rationalisation and the quantity of food. As conception on the farm, we thought we need to have a very beautiful, visible animal, but it is not the best thing, the animals being very fat. The animal should be at a score of 3 , learning to classify the animals according to their characteristics, we have achieved, following the training program, what are their needs and how we could respond to these specific needs.'

During the last interviews about strategic planning one of the farmers said:

'Look at the covering of the silage. That is one of the first things I learned from the project. The feeding quality is far more better now.'

Another farmer said:

'Sometimes the trainings were too theoretical and too long, they could be more practical. Although I learned a lot but I always had to choose between the training and working at the farm.'

\section{Adequacy of the organisation, methods and techniques of training.}

The organisation and logistics could be improved. Incentives to participants to arrive on time and planning of the activities could be better organised. 
Farmers tend to be very pleased about the information provided, which contained valuable information for their own farm activities

Time remains the biggest problem for farmers, especially in situations in which some farmers have no other person to let in the farm to take care of animals and solve any problems that may occur while they are attending a specialised training programme. Overlap (as period) with certain specific periods of farm activity has to be avoided. Time to travel to a training location can be a constraint. 


\section{$5 \quad$ Project learnings}

During the implementation of the project Dairy Chain Development a lot of observations, experiences and learnings have been gained about dairy farming and knowledge exchange in Romania, and especially concerning the dairy sector and Transylvania. This chapter summarises these experiences and learnings. These observations have their importance for everyone who is operating or wants to operate in agricultural business in Romania, dairy farmers and their stakeholders, and for policy makers in Romania.

\subsection{Observations on the dairy project}

\section{Development of knowledge of farmers}

- The need for knowledge and the sense of urgency for acquisition of new knowledge varies between farmers. Some farmers are acting as their father and grandfather did and are not aware of the possibilities of improvement.

- Most of the farmers are not used to spending time on learning activities. It was difficult to realise for them that learning time is working time.

- There is a large difference in knowledge and skills between farmers: most of the younger generation has visited farms abroad which opened their eyes and view about other ways of farming. International experience of the farmer is very important for the success of the farm.

- Farmers' attitude to labour force and internships by students is very important for the stability and quality of the (future) farmer workers.

\section{Development of farms}

- The interviews with farmers at the end of the project show there is a lot of potential for family farms to grow to between 100 and 200 dairy cows and between 200 and 500 ha of land. Further potential would be triggered if farmers dare to invest in robotising the farm. There is a trend that more family farms are willing to cooperate with other farms (buying and selling).

- There seem to be several strategies for further development of family farms: specialisation, cooperation, diversifying (e.g. own processing of milk, tourism), moving to organic.

- Common structure of the farm is a family farm with between 2 and 20 employees. This means that tasks can be divided between different persons: farm worker/farm manager/farm owner with specific competencies. The farm manager is more interested in the managing of the labour and the financial part of the farm. In that case the target group for vocational training is the labour workers. Quality of labour is a problem due to lack of education and attractiveness of working at a farm.

\section{Training of advisors}

- Study groups as a way of knowledge development knowledge sharing is very difficult to start up in Romania. They do not fit into Romanian culture (lot of distrust), but it seems that the new generation of farmers is more open to each other.

- The staff of FCR who are intended to advise the farmers have 2 jobs: contracting farmers based on price agreements and advising on content. This is a very difficult combination related to the position of the staff member to the farmer (trust). Besides, the staff members should have enough time to spend on giving the farmers advice, or even better should have a specialised more position of either (independently) advising the farmers or contracting the farmer.

\section{Linking of the project with other relevant stakeholders (University, banks, etc.)}

- At this moment the most likely means of knowledge development is through education at agricultural colleges and universities. Owners of larger farms often haven an agricultural, veterinarian or technical university education. The project had a good connection with the Agricultural University of Cluj-Napoca, but not with agricultural high schools. 
- Banks and financial institutions have only limited knowledge of the agri-food complex. This will limit the possibilities for financing farm investments.

- Given the history current cooperatives are not seen as the primary representatives of farmers' interests. New and regional cooperatives with young agricultural members might be able to take that role.

\subsection{Recommendations}

- Facilitate peer teaching and support train-the-trainer concepts. Agricultural universities could have a coordinating role in this. There is a lot of interest in strategic management concepts.

- Study groups should be organised for different target groups and the content should be adapted to this group. Take the role of the participant within the farm into account (farm worker/farm manager/farm owner).

- Start study groups with younger motivated farmers.

- Prevent financial dependencies between the organiser/sponsor and participating farmers (willingness to share experience will decline).

- Let participants pay for the advice they receive (perhaps partly but NOT totally sponsored).

- Train the trainer concepts will work if:

- Attention is paid to the role of trainer as facilitator of group processes.

- With involvement of Schools and universities.

- Awareness of the role of the advisor: independency or more commercial (feed advisor). A double role of advisor and contractor is less trustful to the farmer.

- To support individual farm support; mainly larger farms are able to pay for professional advice.

- Support the development of a dairy sector organisation to represent the interests of the dairy farmers.

\section{General conclusions}

- At the end of the project period it seems that the 'climate' for farming in Romania is changing. There is a generation of farmers who is willing to farm at a societal accepted, sustainable ' people friendly' and high tech way. These farmers form an example of modern sustainable farming in the future and they offer a new perspective to young farmers.

- The Romanian government is aware of the level of agricultural education, and is working at an action plan to modernise the agricultural colleges and high schools.

- These developments can open the Romanian door to Dutch and other European farmers who are willing to start a farm in Romania. 


\section{References and websites}

Beldman, A.C.G., D. Lakner and A.B. Smit, 2013. Changing conditions require a higher level of entrepreneurship by farmers: use of an interactive strategic management tool. In: A. Kuipers, A. Rozstalnyy and G. Keane (eds.), Cattle husbandry in Eastern Europe and China; Structure, development paths and optimisation, Wageningen Academic Publishers, EAAP publication No. 135, pp. $125-131$.

Bergevoet, R.H.M., G.W.J. Giesen, H.W. Saatkamp, C.M.J. van Woerkum, and R.B.M. Huirne, 2005. Improving enterpreneurship in farming: the impact of a training programme in Dutch dairy farming. In: 15th Congress Developing Entrepreneurship abilities to feed the world in a sustainable way, Sao Paulo, 14-19 August 2005 / Silva, A.P., Vidal, A.J., Ribeiro, P.G, Sao Paulo: p. 70 - 80.Chesbrough, H., and R.S.

Bergevoet, R.H.M. and C.V. Woerkum (2006). 'Improving the Entrepreneurial Competencies of Dutch Dairy Farmers through the Use of Study Groups.' The Journal of Agricultural Education and Extension 12(1): 25-39.

Rosenbloom, 2002, The role of the business model in capturing value from innovation: evidence from Xerox Corporation's technology spin-off companies. In: Industrial and Corporate Change, 11-3, p. 529-555.

Stanciu, S.T. Romanian Milk market Analysis. SEA - Practical Applications of Science. Volume II, Issue 2 (4)/2014. The Bucharest University of Economic Studies, Romani.

Gray, D., S. Brown and J. Macanufo, 2010. Gamestorming: A Playbook for Innovators, Rulebreakers, and Changemakers. O'Reilly Media.

De Lauwere, C.C., 2005. The role of agricultural entrepreneurship in Dutch agriculture of today. Agricultural Economics 33 (2). - p. 229 - 238.

De Lauwere, C.C., E. ten Pierick, V. Beekman and M.A.P.M. van Asseldonk, 2010. Behavioural change as a key to sustainable agriculture. In: Global food security: ethical and legal challenges, EurSafe 2010, 16-18 September 2010 Bilbao, p. 91 - 96.

Lans, 2009. Entrepreneurial competence in agriculture. Characterization, identification, development and the role of the work environment. Wageningen University, PhD-thesis.

Malak-Rawlikowska, A., A. Kuipers, A. Stalgiene, B. Smit, P. Krištof, B. Schaer and M. Klopčič, with contributions by D. Lakner, N. Tomson, W. Zaalmink and A. Was, 2018, 'Farming with vision'; Strategy, networking, marketing and business planning, Wageningen UR. Official product of project No. 2015-1-PL01-KA202-016871 within the Erasmus+ Program, 67 pp. http://ism.sggw.pl/wp-content/uploads/2019/01/ISM-END.pdf

Popescu, A., 2017, Trends in milk market and milk crisis impact in Romania, Scientific paper series management, economic engineering in agriculture and rural development, Vol, 17, issue 2.

Porter, M.E., 1980. Competitive Strategy. Techniques for analyzing industries and competitors. Free Press.

Porter, M.E., 1998. On Competition, Boston, Harvard Business School. 


\section{Appendix 1}

Table A1.1 Number of dairy cows in Romania in 2016

\begin{tabular}{|c|c|c|c|c|c|c|c|c|}
\hline & $\begin{array}{l}\text { 1-2 dairy } \\
\text { cows }\end{array}$ & $\begin{array}{l}\text { 3-9 dairy } \\
\text { cows }\end{array}$ & $\begin{array}{l}\text { 10-19 } \\
\text { dairy } \\
\text { cows }\end{array}$ & $\begin{array}{l}20-29 \\
\text { dairy } \\
\text { cows }\end{array}$ & $\begin{array}{l}\text { 30-49 } \\
\text { dairy } \\
\text { cows }\end{array}$ & $\begin{array}{l}\text { 50-99 } \\
\text { dairy } \\
\text { cows }\end{array}$ & $\begin{array}{l}>=100 \\
\text { dairy } \\
\text { cows }\end{array}$ & Totaal \\
\hline Nord-Est & 137.220 & 95.880 & 23.720 & 8.190 & 6.300 & 4.850 & 7.840 & 284.000 \\
\hline Nord-Vest & 61.580 & 89.490 & 22.790 & 12.030 & 6.440 & 5.820 & 8.790 & 206.940 \\
\hline Sud - Muntenia & 71.740 & 37.870 & 9.700 & 5.200 & 2.830 & 2.260 & 13.110 & 142.710 \\
\hline Sud-Vest Oltenia & 43.040 & 41.140 & 8.660 & 2.960 & 1.350 & 1.260 & 1.330 & 99.740 \\
\hline Vest & 19.020 & 36.760 & 8.240 & 2.540 & 4.390 & 2.050 & 9.050 & 82.050 \\
\hline Bucuresti - Ilfov & 440 & 630 & 260 & 60 & 70 & 130 & 1.120 & 2.710 \\
\hline
\end{tabular}

Source: Eurostat.

Table A1.2 Number of farms with dairy cows in Romania in 2016

\begin{tabular}{|c|c|c|c|c|c|c|c|c|}
\hline & $\begin{array}{l}\text { 1-2 dairy } \\
\text { cows }\end{array}$ & $\begin{array}{l}\text { 3-9 dairy } \\
\text { cows }\end{array}$ & $\begin{array}{l}\text { 10-19 } \\
\text { dairy } \\
\text { cows }\end{array}$ & $\begin{array}{l}\text { 20-29 } \\
\text { dairy } \\
\text { cows }\end{array}$ & $\begin{array}{l}\text { 30-49 } \\
\text { dairy } \\
\text { cows }\end{array}$ & $\begin{array}{l}\text { 50-99 } \\
\text { dairy } \\
\text { cows }\end{array}$ & $\begin{array}{l}>=100 \\
\text { dairy } \\
\text { cows }\end{array}$ & Totaal \\
\hline Nord-Est & 114.400 & 36.500 & 3.440 & 660 & 330 & 140 & 60 & 155.530 \\
\hline Nord-Vest & 49.920 & 29.570 & 2.600 & 790 & 290 & 150 & 90 & 83.410 \\
\hline Sud - Muntenia & 51.080 & 12.970 & 1.030 & 350 & 140 & 60 & 50 & 65.680 \\
\hline Sud-Vest Oltenia & 32.090 & 14.380 & 1.050 & 230 & 70 & 40 & 10 & 47.870 \\
\hline Vest & 12.880 & 11.330 & 1.060 & 180 & 180 & 50 & 60 & 25.740 \\
\hline Bucuresti - Ilfov & 350 & 190 & 30 & 10 & 10 & 10 & 10 & 610 \\
\hline
\end{tabular}

Source: Eurostat. 


\title{
Appendix 2 Introduction to the background, principles and application of interactive strategic management
}

\author{
Interactive Strategic Management \\ (derived and adapted from: Tomson, N. and B. Smit, 2017, Interactive Strategic Management \\ combined with Canvas Business Modelling in a 'knowledge coalition', In: Seminar Proceedings \\ ENTREPRENEURSHIP and STRATEGIC MANAGEMENT, Edinburgh, 5th of July, 2017, pp. 98 - 109 (part \\ of the 21st International Farm Management Congress Edinburgh, Scotland 2nd - 7th July 2017 'Future \\ Farming Systems'); http://ism.sggw.pl/wp-content/uploads/2017/03/IFMA-2017- \\ seminar_Booklet.pdf)
}

Since 2000, Wageningen Economic Research, the Netherlands, has developed the Interactive Strategic Management-method. This method is based on the theory of strategic management and deals in practice with strategy planning.

The ISM method has been developed in response to the huge changes the European agriculture has experienced in the last decades. Institutional, production and marketing changes, influenced by EU common agricultural policy, but also societal wishes like food safety, animal welfare and the environment, require adaptations of the way farmers produce and sell their products. Entrepreneurial skills are a key factor for survival during such adaptation processes. Many authors studied entrepreneurship in agriculture, agricultural entrepreneur's competences and their ability to adapt to changing economic realities (Bergevoet et al. 2005, De Lauwere 2005, Lans 2009, De Lauwere et al. 2010). Great adaptations can only be successfully planned and carried out through strategic thinking, which however is rarely present among farmers, especially but not exclusively in Central and Eastern Europe (Beldman et al., 2013). Agricultural producers, focused on operational decisions taken 'by the day' often do not see the need for a vision for their enterprise in a long-term, strategic perspective. This is even more the case with farmers in less favourable rural areas, in general with small-scaled farms. Building a future in such areas requires a certain level of entrepreneurial competencies (MalakRawlikowska et al., 2018). Therefore, training in entrepreneurial behaviour and decision making is essential, as are tools to support such trainings. A theory that deals with strategy planning is 'strategic management'. However, this theory is, in general, not incorporated in the consulting and educational efforts towards farming communities (Beldman et al., 2013).

Wageningen Economic Research has applied the Interactive Strategic Management-method including a web-based tool as a training concept in research, educational and commercial projects. The concept has been applied in both individual and group sessions with students and (future) farmers. They learn how to plan the strategy of their (future or imaginary) farm in a structured and solid way. In 2006, the largest agricultural bank in the Netherlands, Rabobank, adopted the concept in the Rabo Opvolgers Perspectief (Rabo Successors Perspective). In this coaching programme, farmers' sons and daughters who want to take over the farm, are trained according to the ISM principles (Beldman et al., 2013). Wageningen Economic Research has also some experience with the method outside the Netherlands, e.g. in Poland, Lithuania, Slovenia, Austria and Sweden (partly in the Erasmus-project ISM+; see also Malak-Rawlikowska et al., 2018).

The ISM method has three main principles: (1) the emphasis is on the entrepreneur; (2) interaction with the environment; and (3) a focus on actual progress or actions of the entrepreneur. We now explain these principles:

a. Placing the entrepreneur (in this case: the farmer) at the centre of the attention means recognising that, instead of an advisor, the farmer himself is responsible for the content of the strategic plan for his farm. The strategy developed by an advisor or expert could not truly fit with 
the individual situation of the farm and the farmer, his personal thinking, goals and abilities. The entrepreneur must therefore write the strategic plan himself; an advisor or, rather, facilitator is only there to guide and stimulate the process. The focus in the ISM training is on strategic choices (3-10 years ahead). This means that tactical choices (choices for the next 1-2 years) and operational issues do not receive much attention. In general, a good strategy is based on a good fit between means and opportunities (Porter, 1980; 1998). Within the ISM method, this is specified in the following way. A good strategy is based on a good match between: a) the entrepreneur: the ambitions and skills of the farmer, his family and/or employees; b) the enterprise: the structure and performance of the farm, and c) the environment: market and society (Malak-Rawlikowska et al., 2015);

b. Interaction with the environment. There is not only a lot of attention during the training sessions about presenting and discussing ideas and views among the participants. Farmers are also challenged, not only during the training but as a basic principle of entrepreneurship, to communicate with one's partner, parents, children, advisors, industry agents etc. and also with citizens and customers. The main reason is: An entrepreneur needs to know how other stakeholders think about him, his farm and his products. Otherwise, he cannot optimally shape his farm;

c. Focus on actual progress or actions of the entrepreneur. It is not enough to show nice pictures and tell nice plans. To be really successful, an entrepreneur needs to translate all those nice ideas into concrete and smart action plans, which he evaluates on a regular basis.

An ISM training is guided by a facilitator. A good trainer recognises and applies the three principles listed. He or she must be able to stimulate farmers to think out-of-the-box and to stimulate them to interact with colleagues and others (Beldman et al., 2013). Facilitators are using game techniques in their trainings like cover story, context map and empathy map (Gray et al., 2010). In the case that the facilitator is an advisor he should not play the role of the 'expert' but rather be the facilitator of the process that the entrepreneur goes through. The facilitator acts like a guide for the entrepreneurs who have to find their own answers. The ISM-facilitators are trained by Wageningen Economic Research.

More details about the ISM-Method and experiences from its implementation in Europe can be found in the paper: Strategic management training for farmers - the case of implementation of the interactive strategic management methodology in Europe (Malak-Rawlikowska et al., 2018). 


\section{Report of workshops 'FARMING WITH VISION' Romania, 2019}

Bert Smit, ${ }^{1}$ Wim Zaalmink ${ }^{1}$ and Pieter Helfferich ${ }^{2}$

${ }^{1}$ Wageningen Economic Research, the Netherlands

${ }^{2}$ Helfferich Consult SRL/Agriprogress, the Netherlands and Romania

\section{Workshop programme}

Two workshops were organised and carried out on the theme of 'Interactive Strategic Management' (ISM) with the slogan 'Farming with vision':

- Cluj: 10 September 2019, University of Agricultural Sciences and Veterinary Medicine Cluj-Napoca (USAMV Cluj), Str. Manastur 3-5, Cluj-Napoca, 400372, Cluj, Romania, 26 participants, organised by Prof. Felix Arion, Director of the Department of Economic Sciences USAMV Cluj/ General Manager of AgroTransilvania Cluster;

- Bucharest: 12 September 2019, USAMV Senate Room, Bulevardul Mărăști 59, București 011464, Romania, 24 participants, organised by Prof. Livia Vidu (USAMV Bucharest).

The agenda of the workshops was the same at both locations:

- Opening, introduction to the University

- Three (Cluj) or one (Bucharest) farm presentation(s) ${ }^{13}$

- Update of the Dutch dairy sector (by Pieter Helfferich)

- Introduction to Interactive Strategic Management (ISM, by Bert Smit)

- Lunch

- Additional information on ISM (Cluj) or discussion in two groups (Bucharest) on the farm presented in the morning

- Closing of the session

At the end of the workshops, a short evaluation form was filled in by the participants that were still present. All participants received a certificate of having attended the workshop, signed by Prof. Arion or Prof. Vidu and by Dr. Smit of Wageningen Economic Research.

\section{Contents of the workshops and issues discussed}

\section{Relevance of strategic management}

The conditions under which farmers are working nowadays are changing rapidly. These changing conditions require a higher level of entrepreneurship for farmers (Beldman et al., 2013a). In former days, farmers only needed to be healthy strong people who could work hard during many hours. In recent decennia, entrepreneurship has become an important aspect of farming and will increasingly be so in the near future.

Developments in the market (globalisation, certification, food safety requirements, and so forth), in the agricultural policy (reform of the Common Agricultural Policy of the EU, trade treaty negotiations, and so forth) and in society in general (e.g. growing concern about environment, nature, biodiversity, landscape, animal welfare, natural resources but also the financial crisis that influences market and policy) urge for higher levels of entrepreneurship (Smit, 2004). There is no clear one-way direction available for the future development of farms, farmers must find their own route to follow.

\footnotetext{
${ }^{13}$ In Bucharest, there was an additional presentation on H20202-project DISARM, in which good practices on reduction of antibiotics use are collected and disseminated. This presentation was given directly after lunch.
} 


\section{The main principles of ISM}

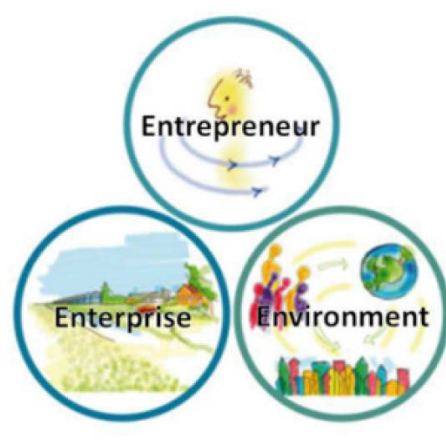

Interactive Strategic Management (ISM) has three main principles:

1. the emphasis on the entrepreneur;

2. interaction with the environment; and

3. focus on actual progress or actions of the entrepreneur.

Wageningen Economic Research, part of Wageningen University \& Research, has developed the concept of ISM making use of the principles of strategic management as described above. The concept was made practical through the development of a tool, SMT (Strategic Management Tool) and has been used in several courses and trainings in the Netherlands and other European countries. Examples are described in the report 'Farming with Vision'.

Presentations in Cluj and Bucharest

In Cluj, three presentations were given on the following farms:

1. Organic holding: Silvania Organic Farms Agricultural Cooperative;

2. Somes Aries Cooperativa Agricola;

3. Start-up Atelierul de Lapte.

In Bucharest, a presentation was given by Ion Militaru (Agroserv Maruta (farm of Nicusor Serban), PhD USAMV), including the dairy factory that was run by the daughter and son-in-law of the farmer.

During and between (Cluj) and/or after (Bucharest) these presentations there was much discussion on the strategies of the three farms. Strategic thinking is based on a thorough analysis of the three 'Es' (Entrepreneur/farmer, Enterprise/farm and Environment (Market, society, policies, physical characteristics), including the mission, vision and ambitions of the farmer (or the board of farmers in case of a cooperative). This concept was generally accepted as a way to improve Romanian farms, their structure and their performance. However, the tool which is used to facilitate the ISM process in groups of farmers (the Strategic Management Tool/SMT) was only presented at an aggregated level (showing four summarising plots for the three Es and the strategies). The long list of questions which need to be filled in, was not presented, so that the participants did not receive insight in the theoretical or practical level of these questions. However:

1. a three-day training could be proposed, in which the different questions receive attention;

2. in an ISM process with Erasmus-partners from Poland, Lithuania, Slovenia, Austria and Sweden SMT was adapted to become well understandable by Eastern-European farmers.

The farm presented in Bucharest received many questions on the products produced by the dairy factory, like the distribution channels, the risk of focusing on a high-premium niche, the exposure of the trademark of the factory, the need and difficulty to produce at a constant quality level and the opportunities to scale-up production within the same farm/factory combination.

Overall, the workshops were evaluated positively for their subject and their level of interaction. 


\section{Family farms in Transylvania}

Opportunities and strategies for Transylvanian dairy farms

Wim Zaalmink and Bert Smit

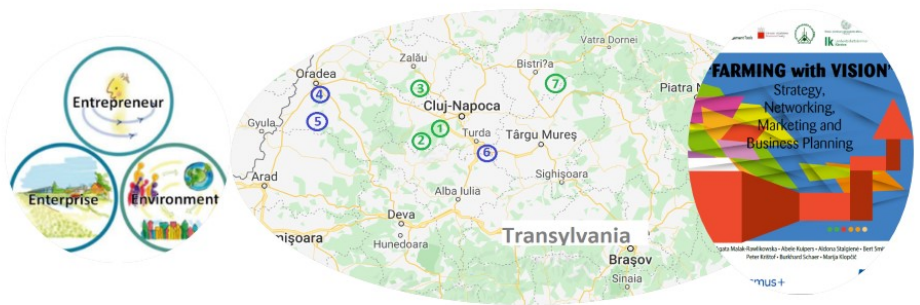

DAGENINGEN

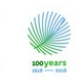

\section{Strategic Management}

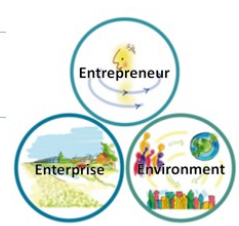

- Focus on strategic choices (3-10 years), not on

operational (daily) or tactical choices (up to 2 years)

- A good strategy is based on a good match with 3 Es:

- Entrepreneur: ambitions and skills of the farmer and family and/or employees

- Enterprise: structure and performance of the farm

- Environment: market and society

\section{Possible strategies}
1. Operational excellence
2. Product leadership
3. Costumer intimacy
4. Producers' network
5. Vertical co-operation (Network integration)
6. Diversification
7. Specialisation
8. Relocation
9. Expansion (hectares, organisation)
10. Down-scaling
11. 'Wait and see' - (no major change) 


\section{Which strategy or strategies to choose?}

How to combine the three 'Es'?

- Environment must give opportunities for a certain strategy

- Farm must be in the right condition for that strategy

- Farmer must be able and willing to work the strategy out into an action plan and real actions!

DAGENINGEN

RSITY R RESEARC

The Transylvanian Farms

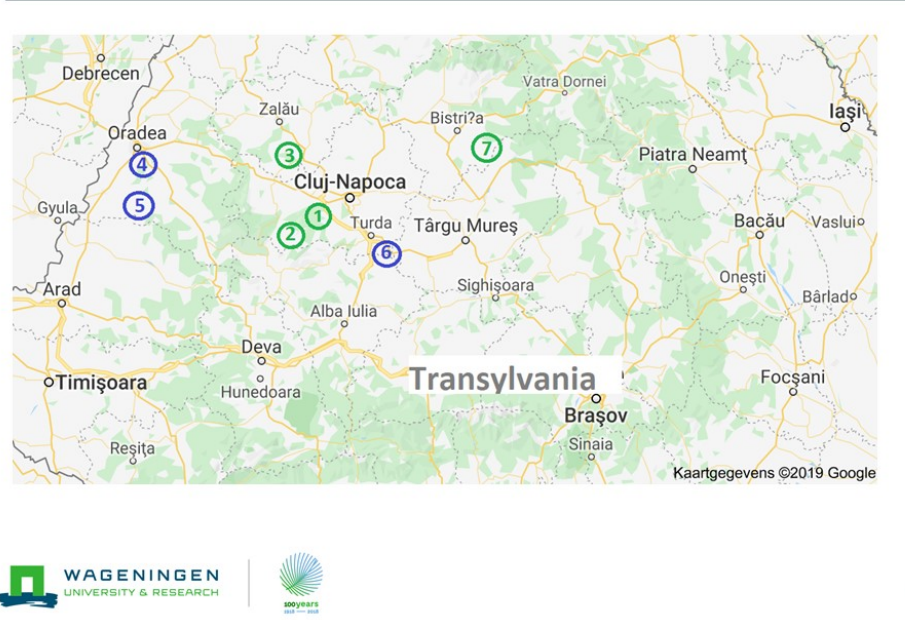

Overall analysis of Transylvanian family farms

Family farms ...

- will develop to farms with 100-200 dairy cows, 200-500 ha of land, mechanised with modern machinery and robots (specialisation strategy)

- are flexible due to commitment of family members and employees

- will cooperate with other farms (buying, selling, processing and exchange machinery)

- will become attractive again to people willing to work at these farms

- can be competitive 


\section{Overall analysis: strategies}

The visited farms showed various potential successful strategies:

- operational excellence (1,000 dairy cows with 18 robots)

- diversification (meat, dairy/arable, cows/sheep/goat, cows and recreation) vertical integration (dispenser, processing)

- product leadership (organic)

- customer intimacy (close cooperation with FrieslandCampina)

- producers network (breeding, buying and sales of products)

- relocation

- expansion (growing in cows)

- wait and see (governmental policies)

WAGENINGEN

\section{Overall analysis: farm location and type}

- Farm location is important for perspective:

- Quality of soil

- Local climate (irrigation possibilities)

- Regional characteristics (availability of partners and willingness to cooperate)

- Distance to processor(s)

- Local or national/international production

- Farm type:

- Mixed vs specialised farms: be circular

- Balance between arable and dairy part of the farm (manure and soil fertility)

- More attention to beef production as part of the integrated farm

WAGENINGEN

\section{Overall analysis: entrepreneur and labour}

- Entrepreneur:

- International experience is very important

- Father-son combinations with different backgrounds is important, awareness and division of competences is crucial

- Labour:

- Quality and availability are a problem

- Farmers' attitude to employees can partly solve problem

- Growing automation and robotisation can be a solution

- Schools don't deliver experience in practice and skilled people

- Farmers need to offer internships 


\section{Overall analysis: environment}

- Registration and restructuring of land very important for farm development

- Buying or renting

- Non-registered land cannot be used as collateral

- Land consolidation

- Environment:

- Higher prospective milk price (quality, transport efficiency)

- Higher demand for organic milk

- Organic meat should be developed

- Cooperation between farmers can lead to lower costs (fertiliser, feed, additives, processing)

\section{Conclusions}

After 7 farm visits ...

The Oradea-Cluj-Bistrita region in Romania is a very nice part of the country full of possibilities, not only for dairy but also for tourism. Think for example of combinations of city and rural holiday experiences.

The growth of animal production will create more added value and will decrease the need for chemical fertilisers cq improve the fertility of the soil (including reducing drought sensitivity).

Family farms will give higher and more commitment to the farm and to the environment. The competitive model can be 100-200 milk cows and 200-500 ha of arable land for the Transylvanian region. This is the maximum span of control of the family farmer.

Depending on the environment, entrepreneur and enterprise, various strategies can be successful for the future.

WAGENINGEN

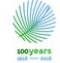

\section{Conclusions ( 2 )}

After 7 farm visits ...

For smaller farms, diversification of meat production, and shorter chains due to self-processing seem to be promising, in addition to bringing consumers and farmers together through touristic activities such as B\&B.

In certain regions with traditional agriculture organic farming is very promising.

Both strategies combined with modern techniques make farming more attractive to young people. Availability of internships at highly mechanised and robot farms is crucial. 


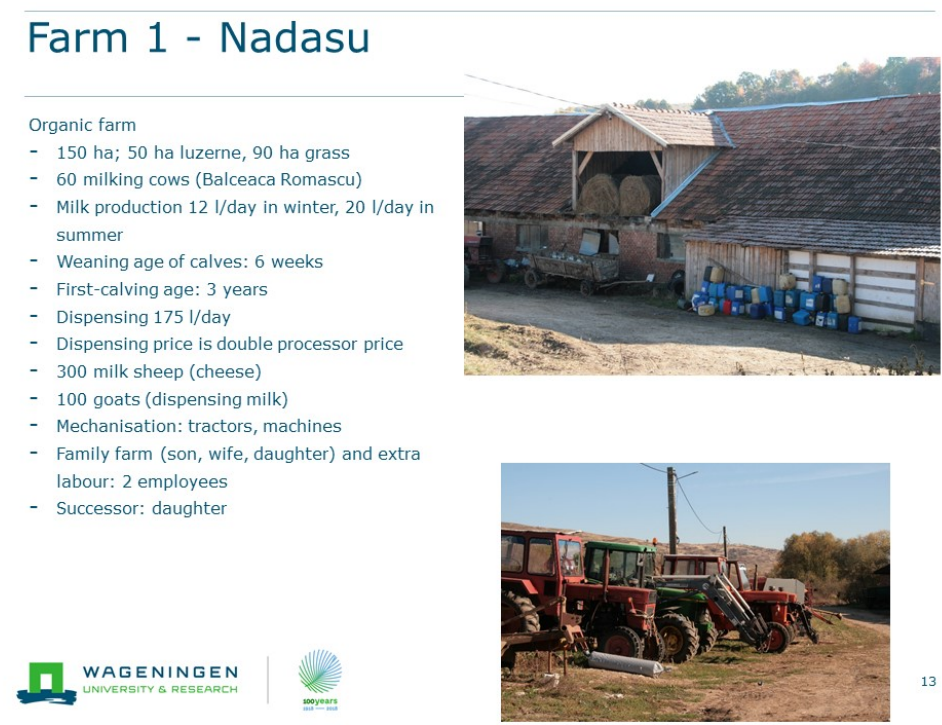

\section{Farm 1 - Entrepreneur}

- Age: 50 years old

- Education: agricultural high school

- Farmer since 18 years

- Machinery oriented

- Presence of a successor

- Takes pleasure in dairy farming
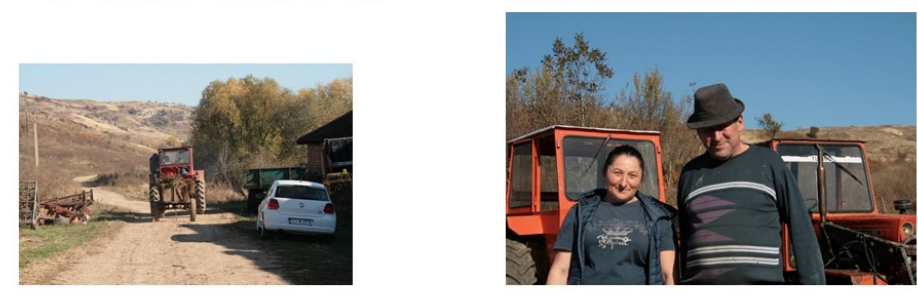

W WAGENINGEN

\section{Farm 1 - Environment}

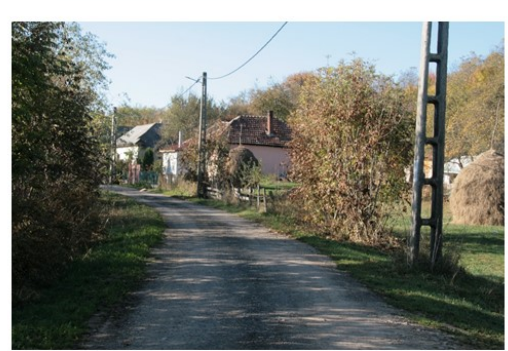

- Farm is located near a small village

- Pasture and arable land in hilly areas

- Long distance to processor

- Climate: hot summers and strong winters

- Loans from bank are difficult

- Growing demand for organic milk

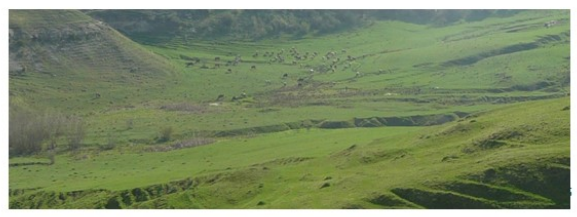




\section{Farm 1 - Analysis}

\section{Strong points:}

Land around the farm

Risk spread

Dispensing machines

Relative near to urban areas

Flexible with (family) labour

Weak points:

Low production

Old barn

Hilly areas

Distance to processo

Trust of banks in investments

Trust in partnerships (banks,

farmers, government)
Opportunities:

+ growing demand for regional products

+ growing awareness and demand for

organic products in Romania and EU

+ beef production based on grass

\section{Threats:}

Competition of more efficient

organic farms on long term,

saturating organic market

- Climate

a WAgENINGEN

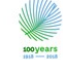

Farm 1 - Strategy

- New barn

- More home-made cheese

- More focus on beef production

- More selling in village (adding more dispensers)

Strategy:

Vertical cooperation, diversification 


\section{Farm 2 - Enterprise, Rasca}

- Organic farm

- 80 ha, 70 ha rented, 10 ha owned

- Pasture, luzerne and corn

- 70 dairy cows

- 38 milking cows

- Production 12 l/day

- Calves weaned after 6 months

- Cheese production for own consumption

- Additional feed supply (potatoes, carrots)

- Male calves for beef production

- Family farm with 2 employees
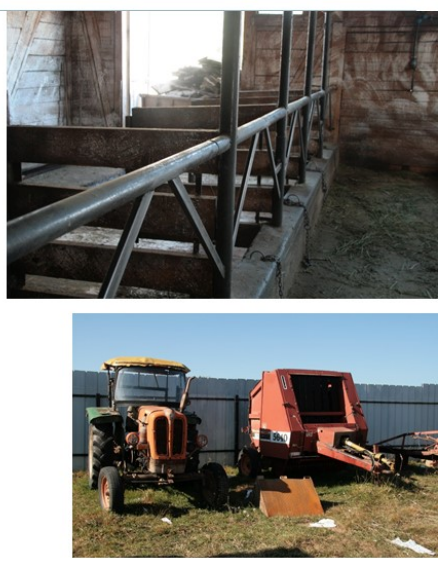

I. WAGENINGEN

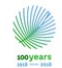

\section{Farm 2 - Entrepreneurs}

- 45 years

- Farmer is cow oriented

- Focus on milk production

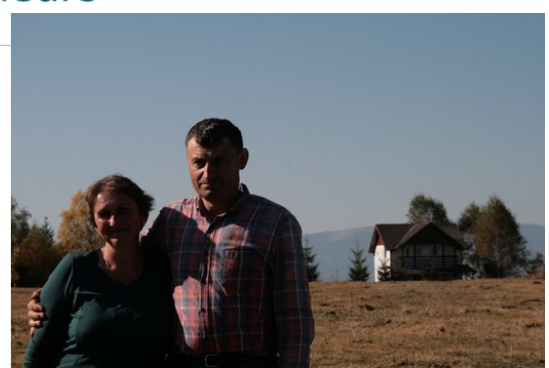

Proud to be a relatively big farmer (in the region)

- Builds on experiences of parents and grandparents

- Learns from experiences of colleague

farmers

Succession is uncertain

D. WAGENINGEN

\section{Farm 2 - Environment}

- Mountainous region

- Strong relation with Napolact

- Regional feed for dairy cows available

- High EU subsidies (unfavourable areas)

- Organic milk price is double the conventional price
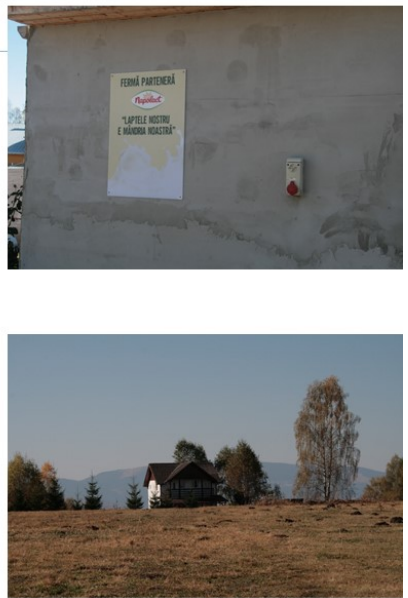


\section{Farm 2 - Analysis}

Strong points:

Land around the farm

Strong and sustainable cows

(10-12 years)

Inefficient logistics in barn

Relatively near to urban areas

Weak points

Hilly areas

No access to EU funds

Trust in/of banks for

investments

Trust in partnerships

Financial technical

management
Opportunities:

+ growing demand for regional products

+ growing awareness and demand for

organic products in Romania and EU

+ beef production based on grass

+ beautiful area with touristic potential

Threats:

Competition of more efficient

organic farms on long term,

saturating organic market

Competition of pensions in the

village

Competition of other sectors

for labour

Climate

\section{Farm 2 - Strategy}

- Upscaling farm to 100 cows

- To become largest dairy farm in region

- Foundation of a cooperation

- Diversification by bed and breakfast

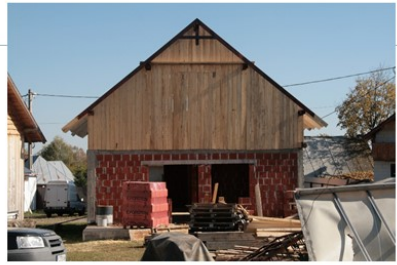

- More value for beef

Family farm is very powerful: flexible and resilient

Strategy:

Diversification, product leadership 


\section{Farm 3 - Enterprise, Petrinda}

- 300 ha land, 60 ha owned

- Alfalfa, maize, grass

- 200 ha not in use

- 120 cows, including 30 milking cows

- Balteata Romanescu cattle and crossbreeds

- Barn (light and air)

- Since 3 years organic

- Return on Investment is zero according to owner

- 4 foreign labour forces, own and foreign labour hard to get

- Soil quality high

- High mechanisation costs

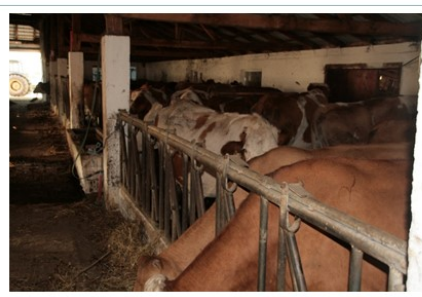

DAGENINGEN
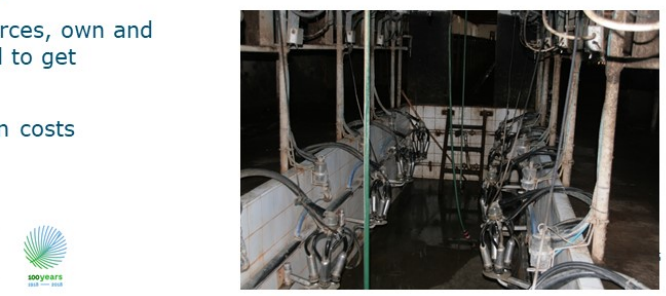

\section{Farm 3 - Entrepreneur}

- 40-50 years old

- Has worked before in Spain/Portugal

- Has invested a lot in the farm

- No succession (does not want children to take over the farm)

- Finds it difficult to find labour forces

- Attached to animals, but enjoys constructing the buildings

- Is critical about the governmental rules

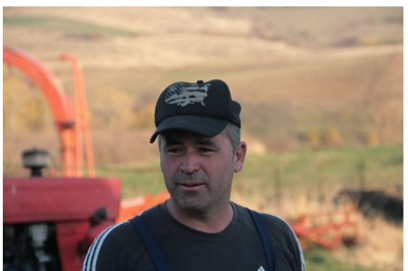

- Active in breeding organisation

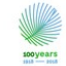

\section{Farm 3 - Environment}

- In rural area

- Lots of land around the farm

- Good soil fertility

- Hard to find qualified labour

- Land registration is a problem

- Bank loan is difficult

- Hard to define European projects
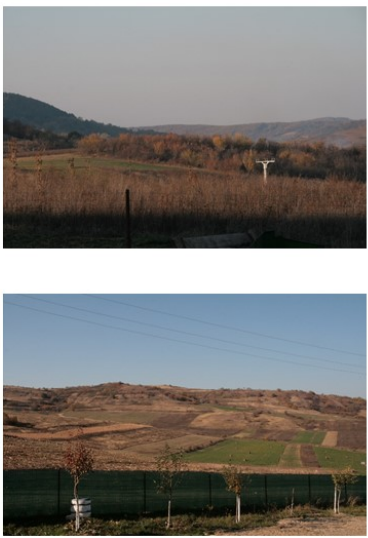


\section{Farm 3 - Analysis}

\section{Strong points:}

Soil quality

Land around the farm

Low costs for construction
Opportunities:

+ growing demand for regional products

+ growing awareness and demand for

organic products in Romania and EU

Threats:

Weak points:

Entrepreneur is more construction

worker than dairy farmer

Labour hard to get

Motivation of farmer

Profitability of the farm

Grass availability

Social position (family is elsewhere)

Availability of capital

- Competition of more efficient

organic farms on long term,

saturating organic market

Competition of pensions in the

village

Competition of other sectors

for labou

Climate

WAGENINGEN

\section{Farm 3 - Strategy}

- Labour from Spain or Vietnam

- Wait and see

- Sell the farm in case of value increase of land and farm

Strategy

Wait and see 


\section{Farm 4 - Enterprise Santandrei}

- 1,000 ha of land (wheat, sunflower, corn, mais silage etc)

- Land split up in many plots, on distance of farm

- Started in 1998, delivering to FrieslandCampina since 2002

- 250 Holstein cows, 100 dairy cows (milking)

- $3,2 \%$ protein, $4 \%$ fat

- Labour: lot of foreign labour. Milking labour is problem.

- Old barns, need to be renewed
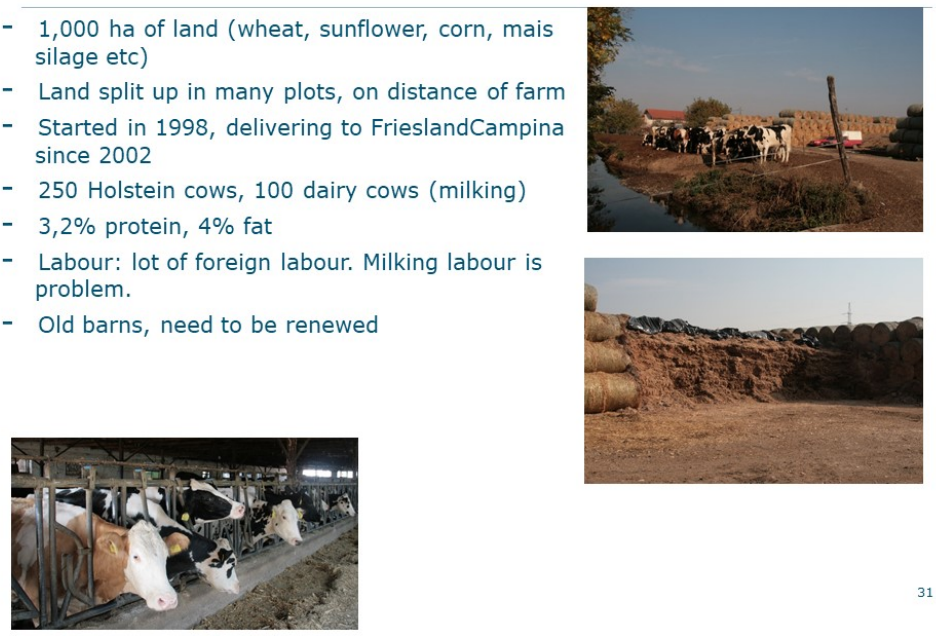

\section{Farm 4 - Entrepreneur(s)}

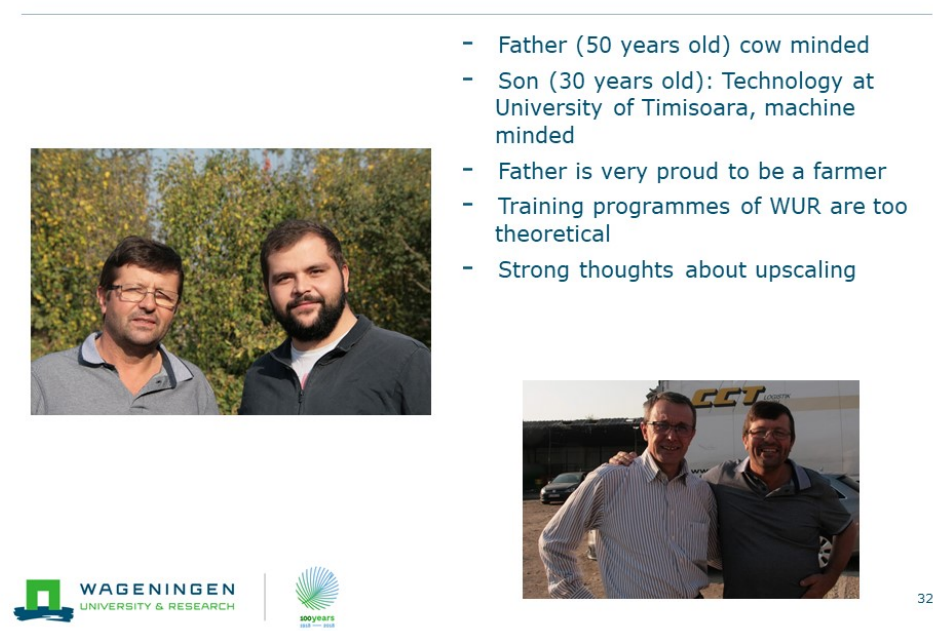

\section{Farm 4 - Environment}

- Location far away from processor

- Near village

- Land split up and at a distance

- Soil sensitive to drought/no possibilities for irrigation

- Land registration not completed

- No financing possibilities
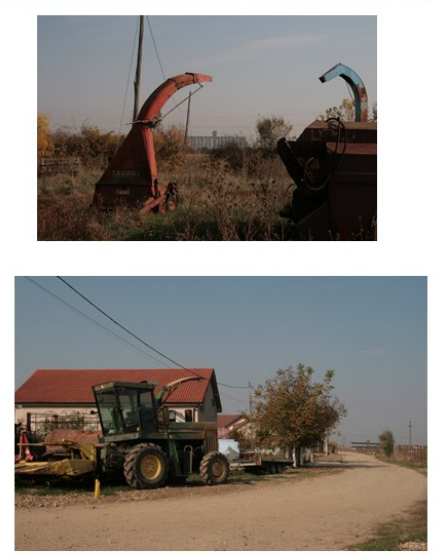


\section{Farm 4 - Analysis}

Strong points:

- Mechanisation knowhow

- Successor
Opportunities:

+ Low cost price strategy

+ High tech (robotisation)

Threats:

Politics, for examples topping

off subsidies for big farms

Climate changes
- Disbalance between amount of animals and arable land

Outdated barns and

equipment, insufficien

ventilation

Current location not suitable

for increase in dairy

production, in urban area and

far from arable land

a Wageningen

WAGENINGEN

\section{Farm 4 - Farmer's strategy}

- Feed the population by upscaling to a 1,000-dairy-cow high-tech farm

- Financing by finding an investor

- New location is available near most of the plots

- Farm growth needed to higher/lower prices

Strategy:

Relocation, operational excellence

Note according to farmer: Strategies as organic and self processing only suitable for smaller farms 


\section{Farm 5 - Enterprise Batar}

- Part of old state farm

- 600 ha (rented) land: 40 ha grass, alfalfa, wheat, corn, sunflower

- 200 cows, 75 milking cows (Holstein and mixed)

- 12 employees

- Highly mechanised with new machines

- Soil quality is very good

- Delivering to Friesland

CampinaSince 2008
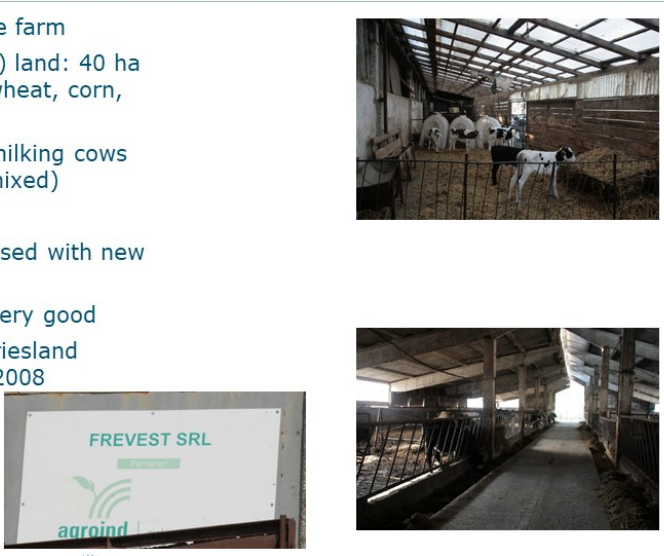

WAGENINGEN

Farm 5 - Entrepreneur

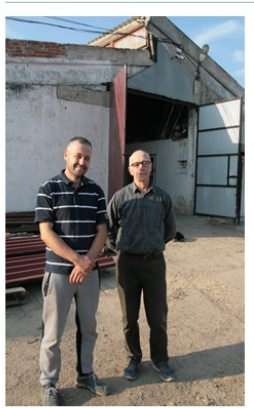

- Father 75 years old, cow oriented, zootechnician

- Son 40 years old, technique oriented, electrician

- Eager to learn, very positive about trainings

- Uses urea content in milk as feed ratio indicator

- Open mind for advice from other advisors (Nutrivice)

- Good relation with labour people

- Availability of internships for high school students at farm

- Cooperative mentality

- Has calculated cost price of milk WAGENINGEN
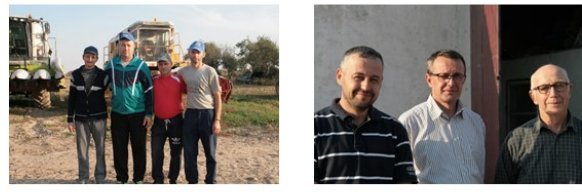

\section{Farm 5 - Environment}

Soil quality very good sensitive for draught

- Quality of labour for milking is a problem

- Long distance to processor -> lower milk price

- Land registration not completed; now on top of financing opportunities

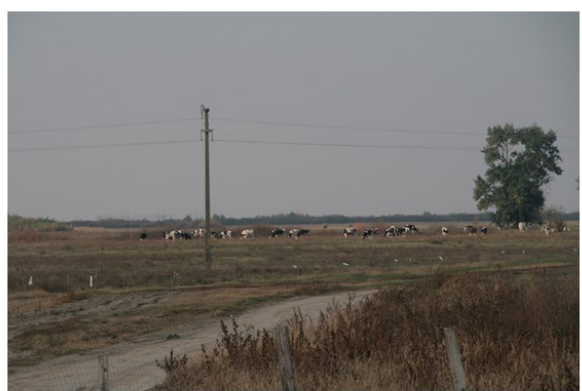




\section{Farm 5 - Analysis}

Strong points:

Mechanisation knowhow

Family farm with successor

Good HRM

Eager to learn

Two legs (dairy and arable)

Weak points:

Disbalance between amount of

animals and arable land

(manure)

Outdated too small milking

parlour, insufficient ventilation

No additional financing via

bank possible

- Wageningen
Opportunities:

+ Growth to low cost price strategy

+ High tech (robotisation)

+ Partnership with other farmers

Threats:

Politics, for examples topping

off subsidies for big farms

- Climate changes

Labour availability

\section{Farm 5 - Strategy}

- Choosing beef production is not an option

- Upscaling to 120 milking cows and 2 milking robots

- Looking for private investor

- More cooperation

Strategy: diversification dairy and arable, producers network 


\section{Farm 6 - Enterprise in Visoara}

- 1,500 ha land: corn, alfalfa, triticale, hay, maize

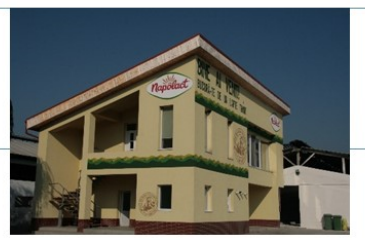

200 dairy cows in 2 flocks: HF and mixed breed

- Own bulls fattening to $600 \mathrm{~kg}$

- 30 persons foreign labour

- State farm

- New equipment in old barn

- Own feed mill

- Started in 1997

- Land in plots, not all registered

- EU-founded projects

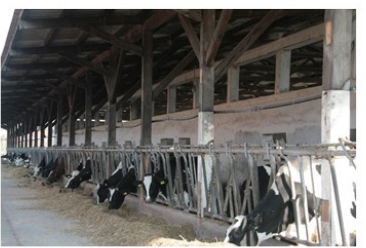

D. WAGENINGEN

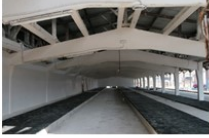

\section{Farm 6 - Entrepreneur}

- 55-60 years old

- Farm started with father (early nineties)

- Farmer has more affinity with arable part of farm

- Farmer is a real networker

- Children will not take over the farm
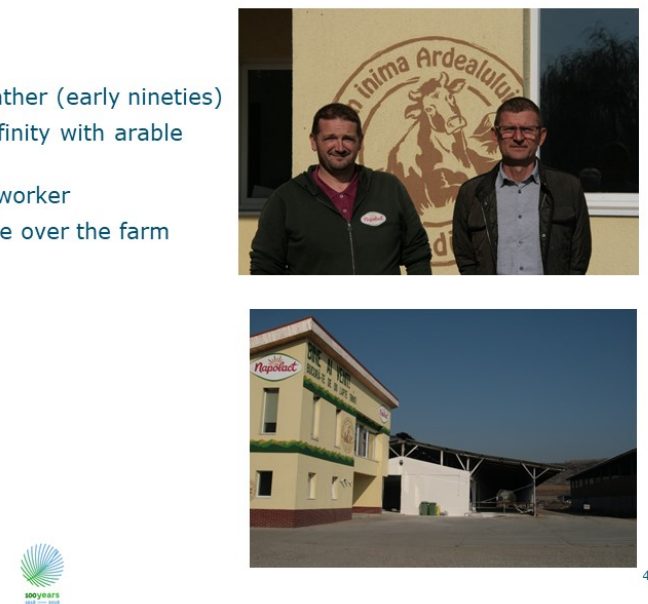

\section{Farm 6 - Environment}

- Lot of land plots

- Bad land registering

- Financing new activities is difficult

- Climate too dry

- Near processor

- High milk price

- Near consumers

- Subsidy is crucial for continuity, depending on governmental policies
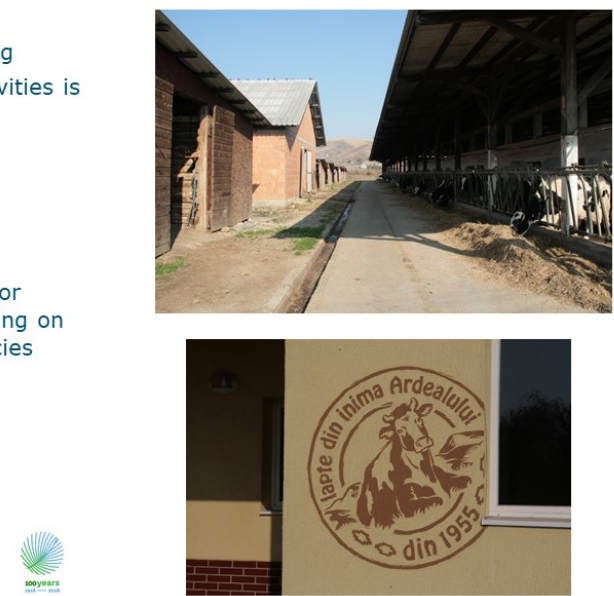


\section{Farm 6 - Analysis}

\section{Strong points}

Farm scale

Risk spread dairy and arable

Proper and well organised

Qualified labour

Farm management: veterinarian

and 2 engineers

Good relation with Napolact

High milk price

Farmer is a good networker

Farmer has good relation with

labour men

Farmer has clear strategic vision

Irrigation possibilities

Opportunities:

+ Low cost price strategy

+ regional products

+ market for special concentrates

WAGENINGEN

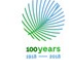

Weak points

Barn overcrowded

Floor bedding needs to be improved

Overcapacity of feed mill

Farmer has more affinity with the

arable part then with the dairy part

Threats:

Politics, for example topping

off subsidies for big farm

Draught including climate

change

other:

High milk price

Good relation with processor

Land registration

Maximum financed

\section{Farm 6 - Farmers strategy}

- Growth to 200 dairy cows

- Split farm into 2 parts: dairy and arable

- More cooperation with Napolact

Overall strategy: Customer intimacy

Family farms:

- span of control is important

- important for quality, motivation and involvement

D. WAGENINGEN 


\section{Farm 7 - Enterprise Bistrita}

- 100 ha land (grass, maize, alfalfa)

- 70 milking cows: Holstein Friesian, Swiss Holstein and Red Holstein

- 2 employees

- milking robot

- House at location for employee families

- Started in 2010

- In conversion to organic

- Milk production $30 \mathrm{l} /$ day

- Fertile soil

- Stabil humidity

- Land around the farm I. WAGENINGEN

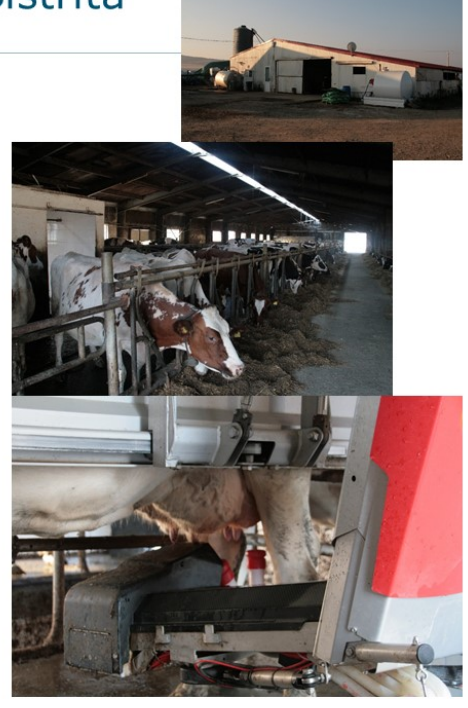

\section{Farm 7 - Entrepreneur}

- 37 years old

- Experience abroad (Germany, the Netherlands)

- Lot of attention to cows and animal welfare

- Cooperative mentality

- Networker

- Innovative and eager to learn

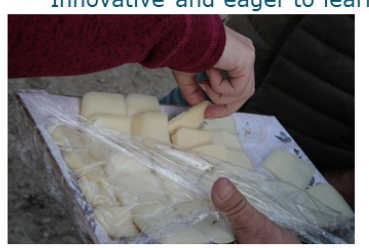
WAGENINGEN UNIVERSITY S RESEARCH
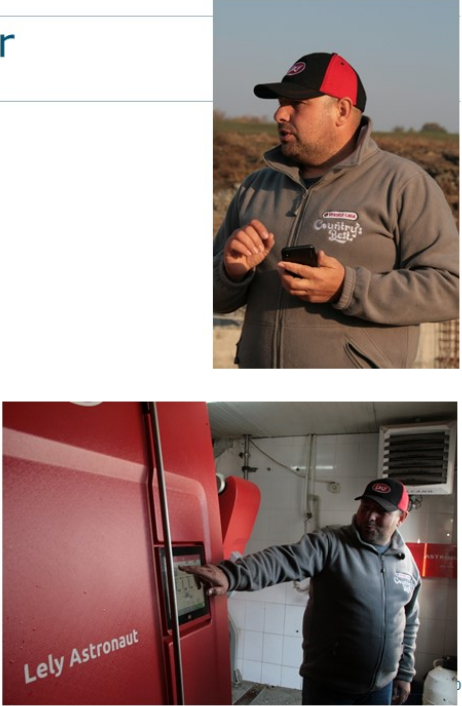

\section{Farm 7 - Environment}

- Fertile soil, suitable for dairy farming

- Land around the farm

- Good climate

- In rural area, near village

- 3 organic processors nearby

- More robot milking farms and organic farms nearby

- Study group of farmers

- Regional cooperation in breeding (Biagen Swiss)

- Expensive land

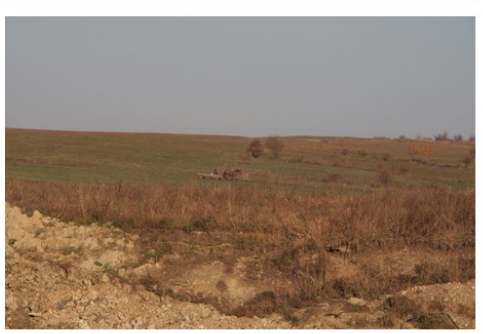




\section{Farm 7 - Analysis}

Strong points

Location of the farm (soil quality)

Near processor

Farmer is good cow farmer

Passion for genetics, animal welfare

and organic farming

Networke

Takes social care of employees

Big scale for organic farm

Opportunities:

+ Growing organic market

+ High tech (robotisation), no additiona

labour needed

+ Cost price leadership in organic

+ Partnership with other farmers for

concentrate

WAGENINGEN
Weak points

Current farm size too small

Less arable farming minded

Purchase of expensive organic

concentrates is needed

Threats:

Politics, for examples topping

off subsidies

Labour availability

Long-term saturation of

organic market

\section{other points}

Growing demand for organic food

Qualified labour hard to get -

$>$ robotisation

Cooperation between farmers

is needed

\section{Farm 7 - Farmers strategy}

- Expanding farm to 200 milking cows, 200 ha land and 3 milking robots units

- Using EU funds

- Conversion to organic farming

- Cooperation with other farmers (genetics, concentrates etc.)

- Own cheese processing

\section{Strategy}

Mix of producers network, product leadership, expansion and in future vertica integration

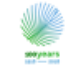

Family farms in

Transylvania:

opportunities and

strategies

Wim Zaalmink

wim.zaalmink@wur.n

₹ 0031320293530

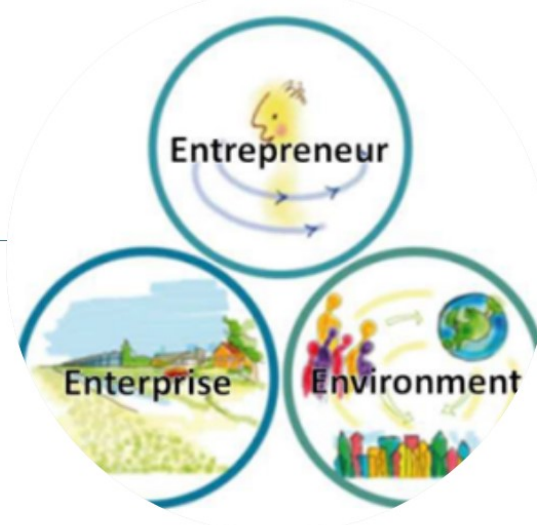

The project Dairy Chain Development Romania is

financed by Topsector Agrifood, Ministry of Agriculture,

WAGENINGEN

Nature and Food Quality of the Netherlands. 
Wageningen Economic Research P.O. Box 29703

2502 LS The Hague

The Netherlands

$\mathrm{T}+31(0) 703358330$

E communications.ssg@wur.nl

www.wur.eu/economic-research

Wageningen Economic Research REPORT

2020-015
The mission of Wageningen University \& Research is "To explore the potential of nature to improve the quality of life". Under the banner Wageningen University \& Research, Wageningen University and the specialised research institutes of the Wageningen Research Foundation have joined forces in contributing to finding solutions to important questions in the domain of healthy food and living environment. With its roughly 30 branches, 5,000 employees and 12,000 students, Wageningen University \& Research is one of the leading organisations in its domain. The unique Wageningen approach lies in its integrated approach to issues and the collaboration between different disciplines. 



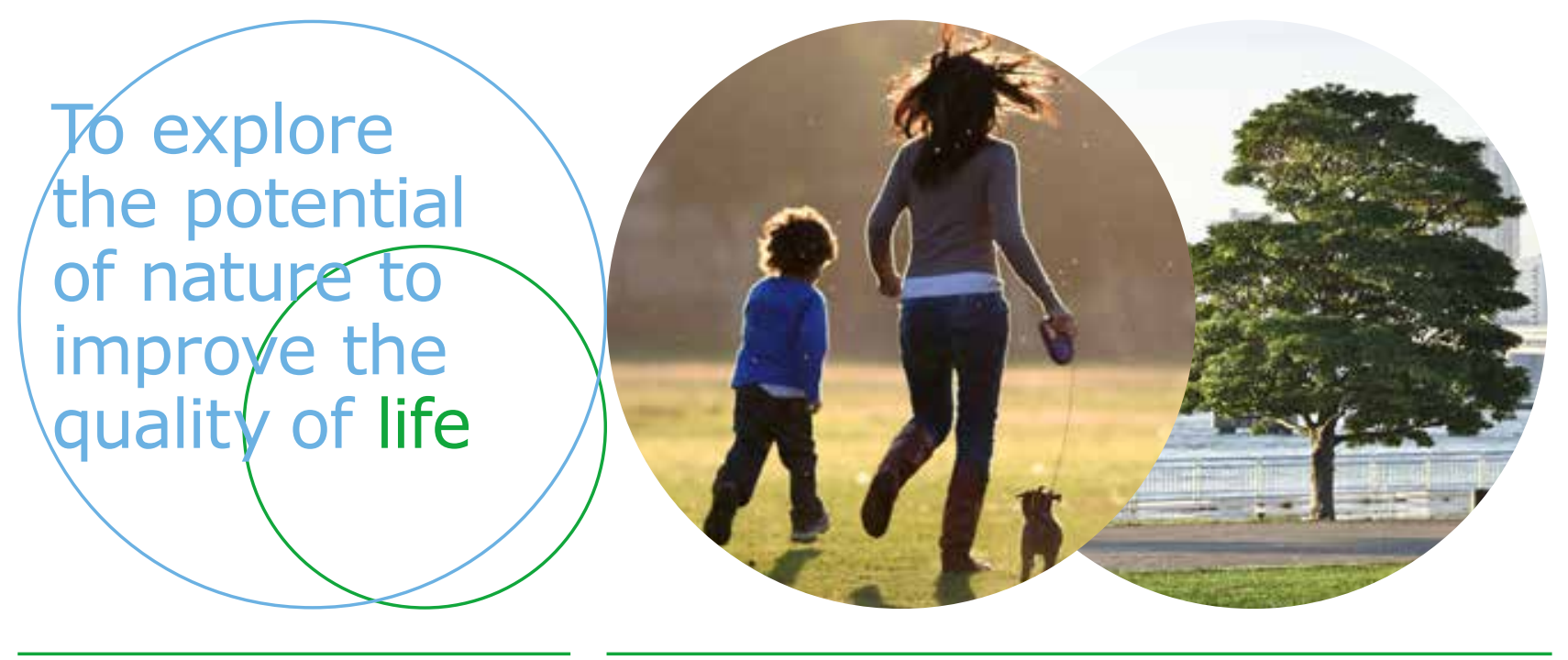

Wageningen Economic Research P.O. Box 29703

2502 LS Den Haag

The Netherlands

$\mathrm{T}+31(0) 703358330$

E communications.ssg@wur.nl

www.wur.eu/economic-research

Report 2020-015

ISBN 978-94-6395-316-0
The mission of Wageningen University \& Research is "To explore the potential of nature to improve the quality of life". Under the banner Wageningen University \& Research, Wageningen University and the specialised research institutes of the Wageningen Research Foundation have joined forces in contributing to finding solutions to important questions in the domain of healthy food and living environment. With its roughly 30 branches, 5,000 employees and 12,000 students, Wageningen University \& Research is one of the leading organisations in its domain. The unique Wageningen approach lies in its integrated approach to issues and the collaboration between different disciplines. 